\title{
Cryopreservation of Human Stem Cells for Clinical Application: A Review
}

\author{
Charles J. Hunt \\ UK Stem Cell Bank, National Institute for Biological Standards and Control, Health Protection Agency, South Mimms, Potters Bar, UK
}

\section{Keywords}

Biopreservation - Storage $\cdot$ Stem cell .

Human - Cell line - Cryopreservation .

Vitrification - Pluripotency · Embryonic stem cell . Induced pluripotent stem cell

\section{Summary}

Stem cells have been used in a clinical setting for many years. Haematopoietic stem cells have been used for the treatment of both haematological and non-haematological disease; while more recently mesenchymal stem cells derived from bone marrow have been the subject of both laboratory and early clinical studies. Whilst these cells show both multipotency and expansion potential, they nonetheless do not form stable cell lines in culture which is likely to limit the breadth of their application in the field of regenerative medicine. Human embryonic stem cells are pluripotent cells, capable of forming stable cell lines which retain the capacity to differentiate into cells from all three germ layers. This makes them of special significance in both regenerative medicine and toxicology. Induced pluripotent stem (iPS) cells may also provide a similar breadth of utility without some of the confounding ethical issues surrounding embryonic stem cells. An essential pre-requisite to the commercial and clinical application of stem cells are suitable cryopreservation protocols for long-term storage. Whilst effective methods for cryopreservation and storage have been developed for haematopoietic and mesenchymal stem cells, embryonic cells and iPS cells have proved more refractory. This paper reviews the current state of cryopreservation as it pertains to stem cells and in particular the embryonic and iPS cell.

\section{Schlüsselwörter}

Biologische Konservierung · Lagerung · Stammzelle · Mensch · Zelllinie - Kryokonservierung ·

Vitrifizierung · Pluripotenz · Embryonale Stammzelle . Induzierte pluripotente Stammzelle

\section{Zusammenfassung}

Stammzellen werden seit vielen Jahren klinisch genutzt. Hämatopoetische Stammzellen werden für die Behandlung sowohl von hämatologischen als auch nichthämatologischen Erkrankungen eingesetzt. Mesenchymale, aus dem Knochenmark stammende Stammzellen hingegen sind einerseits Gegenstand von Laborversuchen, andererseits haben sie bereits Eingang in erste klinische Studien gefunden. Obwohl diese Zellen sowohl Multipotenz und Expansionspotential aufweisen, bilden sie in der Zellkultur keine stabilen Zelllinien aus, was vermutlich ihre Anwendungsbreite in der regenerativen Medizin limitieren wird. Menschliche embryonale Stammzellen sind pluripotente Zellen, sie sind dazu in der Lage, stabile Zelllinien auszubilden, welche die Fähigkeit behalten haben, sich in Zellen aus allen 3 Keimblättern zu differenzieren. Dies verleiht ihnen eine besondere Bedeutung sowohl für die regenerative Medizin als auch für toxikologische Untersuchungen. Induzierte pluripotente Stammzellen (iPS-Zellen) könnten einen ähnlich breiten Anwendungsbereich aufweisen, ohne dass dabei mit den störenden ethischen Bedenken wie bei den embryonalen Stammzellen umgegangen werden muss. Eine essentielle Voraussetzung für eine kommerzielle und klinische Anwendung von Stammzellen ist die Existenz von geeigneten Kryokonservierungsverfahren zur Langzeitlagerung. Während es für hämatopoetische und mesenchymale Stammzellen bereits effektive Methoden gibt, ist das Problem für embryonale und iPS-Zellen noch nicht gelöst. Diese Arbeit gibt einen Überblick über den derzeitigen Stand hinsichtlich der Kryokonservierung soweit sie Stammzellen und insbesondere embryonale Zellen und iPS-Zellen betrifft.

\begin{tabular}{ll}
\hline KARGER & $\oplus$ 2011 S. Karger GmbH, Freiburg \\
Fax+497614520714 & Accessible online at: \\
$\begin{array}{l}\text { Information@Karger.de } \\
\text { www.karger.com }\end{array}$ & www.karger.com/tmh
\end{tabular}




\section{Introduction}

The application of stem cells to treat human disease is by no means new. Bone marrow was first transplanted in the 1950s [1, 2], although the first major breakthrough came in 1968 with two reports of successful allogeneic transplantation in two patients: one with an X-linked lymphopenic immune deficiency and the other with Wiskott-Aldrich syndrome [3, 4]. More recently, in 1988, the first successful transplant was performed using umbilical cord blood on a child with Fanconi's anaemia [5]. Whether sourced from bone marrow, umbilical cord blood or, predominantly today from mobilised peripheral blood, the haematopoietic stem cell has developed into the most common source of cells for cell-based therapies for both haematological and non-haematological disease [6, 7]. A recent world-wide retrospective survey of haematopoietic stem cell transplantation (HSCT) from 1,327 participating centres in 71 countries reported over 51,000 first HSCTs (43\% allogeneic) for 2006 [8], while the most recent activity survey from the European Group for Blood and Marrow Transplantation (EBMT), reporting for 2008, showed a total of over 30,000 HSCTs of which $90 \%$ were first transplants [9]. Whilst the main indications were predominantly for leukaemias and lymphomas, over $12 \%$ were for solid tumours and non-malignant disorders.

\section{Mesenchymal Stem Cells}

A second, separate non-haematopoietic stem cell population with multi-lineage potential, residing in the bone marrow, was identified by Friedenstein et al. in 1976 [10]. These stromal cells, variously known as mesenchymal stem cells, marrow stromal stem cells, or mesenchymal stromal cells (MSCs), are capable of differentiation to give rise to bone (osteocytes), cartilage (chondrocytes) and fat (adipocytes) [11] when induced ex vivo. In addition to bone marrow, these cells have been reported in an increasing range of tissues including peripheral blood [12], umbilical cord blood [13], placenta [14], amniotic fluid and membrane [15, 16], dental pulp [17], deciduous teeth [18] and adipose tissue [19]. The incidence of these cells in tissue is extremely low, ranging from around $0.00003 \%$ of nucleated cells in cord blood to $0.001-0.01 \%$ of nucleated cells in marrow, though this decreases with age [20]. Adipose tissue has been shown to have a higher proportion of MSCs (approximately 2\% in the stromal vascular fraction) with a differentiation capacity that extends beyond the mesenchymal lineages [21]. A rich source of MSCs is the perivascular compartment surrounding the vessels of the umbilical cord (with a reported frequency of 1 in 300 of the nucleated cell population) [22]. These have also demonstrated multilineage potential in clonal studies; differentiating to five mesenchymal lineages: bone, cartilage, fat, muscle, and fibrous tissue [23]. The plasticity of MSCs has been well documented [24], and successful differentiation to a wide variety of lineages has been demonstrated including those above and also cardiomyocytes [25], hepatocytes [26], neurons [27] and endothelium [28, 29] though not without question [30, 31]. Recently, a multipotent stem cell (termed a multi-lineagedifferentiating, stress-enduring or 'Muse' cell) capable of giving rise to all three germ layers and expressing a set of genes associated with pluripotency, including Oct 3/4, Sox 2 and Nanog, has been isolated and clonally selected from bone marrow stromal cells [32]. A similar pluripotent stem cell type has also been isolated from human umbilical cord blood [33]. This, termed an unrestricted somatic stem cell, could also be differentiated to all three germ layers but did not express the major pluripotency factors. However it did display an epigenetic signature that suggested a 'poised' epigenetic state for the pluripotency genes, thus preserving the cells' pluripotent potential [34]. These cell types may help to explain the reported ability of MSCs to differentiate to cells of all three germ layers.

Unlike the haematopoietic stem cells from bone marrow and cord blood, plastic-adherent MSCs can be expanded in culture without the loss of differentiation capacity. However these cells show a finite life span of anywhere between 15 and 50 population doublings $[24,35]$ before successive passaging reduces the proliferative capacity and multi-lineage differentiation potential $[36,37]$. Moreover, and unlike haematopoietic stem cells which express common surface markers (e.g. CD34 and CD133), MSCs lack a unique identifying phenotypic marker and are characterised by a set of minimum criteria including the presence/absence of certain specific markers and their in vitro differentiation capacity in response to specific stimuli [38]. Whilst their expansion capability permits the development of a number of MSC-based therapies [39, 40], this finite lifespan, passage-related loss of differentiation capacity, and lack of a specific marker or markers has implications in terms of quality control and batch variation when generating stem cells for commercial and clinical application.

\section{Embryonic Stem Cells}

Pluripotent human embryonic stem (hES) cells, unlike MSCs, have, for all practical purposes, an unlimited capacity for selfrenewal and in culture maintain their pluripotent capacity to differentiate into cell types from all three germ layers, as demonstrated by their ability to form teratomas in SCID mice. Though first isolated from surplus in vitro fertilised blastocysts in 1994 [41], it was not until 1998 that the first stable hES cell line was established by Thomson et al. [42]. The capacity of these cells to undergo virtually infinite expansion and asymmetric cell division with differentiation into cells of ectodermal, endodermal and mesodermal origin was confirmed some 2 years later [43]. Since then, hundreds of stem cell lines have been derived world-wide from blastocysts of fresh and cryopreserved supernumerary embryos as well as from morula [44], single blastomeres [45], arrested embryos and embryos discarded after pre-implantation genetic diagnosis $[46,47]$. 
Phenotypically and in contrast to MSCs, hES cells express a set of surface and intracellular markers which, while not exclusive to embryonic stem cells, nevertheless characterise these cells. This canonical set of markers includes the stagespecific embryonic antigens SSEA-3 and SSEA-4, TRA-1-60, TRA-1-81, CD9 and CD133 (also expressed by other stem cell populations), Thy-1 (CD90), MHC class 1 and the intracellular transcription factor Oct 3/4 [48]. Undifferentiated cells also show high levels of alkaline phosphatase and telomerase activity and generally maintain a normal karyotype over extended periods in culture though there have been some reports of culture adaptation generally, but not exclusively, at high passage involving karyotypic and genotypic changes [49, 50].

\section{Induced Pluripotent Stem Cells}

A very recent development, with potentially a profound significance for clinical therapy has been the generation of induced pluripotent stem (iPS) cells from somatic cells [51-53]. The reprogramming of human somatic cells to an embryonic stem cell-like pluripotent state, through the forced expression of key transcription factors, was first demonstrated by Takahashi et al. in 2007 [54] concurrently with two other groups $[55,56]$. Almost immediately it was shown that such cells could be generated from patient-specific cells for a wide variety of disease states [57] and from a wide variety of somatic cell types [58]. The generation and use of iPS cells particularly for autologous stem cell therapy poses fewer ethical problems when compared to the derivation and use of embryonic stem cells. However, whilst these cells have been shown to be embryonic-stem cell-like, there are small but potentially significant differences in their gene expression patterns [59]; the functional significance and effect on clinical utility of which remain uncertain. The methods of generation too pose some concern for their clinical application: the use of lentiviral and retroviral vectors as well as of oncogenes (Myc and Klf4) together with the low efficiency of reprogramming techniques may compromise their growth and developmental characteristics as well as their clinical utility [60]. Differences between iPS and hES cells in their relative ability to undergo directed differentiation and a recent report that iPS cells derived from different adult tissues varied substantially in their teratomaforming properties [61] all argue for caution and continued research with hES cells if the full potential of stem cell therapies is to be realised.

\section{Stem Cells for Clinical Therapy}

The ability of stem cells from whatever source, but particularly embryonic stem cells, to produce a theoretically unlimited supply of normal, differentiated cells has focussed attention on the potential importance of these cells in both toxicology and drug discovery $[62,63]$, tissue engineering [64, 65] as well as gene and cellular therapy $[66,67]$ for a wide range of human diseases including Parkinson's and other neurodegen- erative diseases [68-70], diabetes [71, 72] and cardiac and vascular therapy $[73,74]$. In a recent editorial in Regenerative Medicine [75], Mason and Manzotti, using a definition for a regenerative medicine as 'that which replaces or regenerates human cells, tissue or organs to restore normal function', argue that the cell therapy sector (both public and commercial) is likely to impact on a huge diversity of medical specialities and applications ranging from conventional cell, tissue and organ transplantation, through transient cell therapies that disrupt or reduce natural disease progression, to tissue engineering and bioaesthetic cell-based treatments. Respected commentaries on the potential of the regenerative medicine field have plotted the development of regenerative medicine therapies since the early 2000s and have anticipated a substantial growth in this area based on progress so far [77]. By 2007 over a million patients had been treated, and European licensing authorities were seeing a sharp increase in the number of applications in the pipeline. From a commercial perspective, this positive benefit to human health has a current world-wide market for regenerative medicine of between USD 2 and 5 billion, with US sales of commercially available stem cell therapies alone valued at USD 15.2 million in 2007 and USD 16.5 million in the first 2 quarters of 2008. The stem cell market, including therapies, cord blood banking and drug development tools, has been projected to achieve annual growth of $29 \%$, resulting in sales of more than USD 11 billion by 2020 . World-wide, there are currently over 800 clinical trials listed on the US Clinical Trials website which are recruiting to studies in which the search terms 'mesenchymal stem cell' or 'adult stem cell' are used and 'stem cell transplant' appears in the intervention [78]. MSCs are being used clinically in trials as diverse as cirrhosis, left ventricular dysfunction, and graft-versus-host disease [79, 80], while trials of a neural stem cell line for the treatment of stroke patients and oligodendrocyte progenitor cells derived from hES cells for the treatment of spinal injury have just been announced [80, 81]. However, in order to provide safe, quality-controlled cells for both autologous and allogeneic clinical therapy, regardless of the cell source, the principles of good manufacturing practice (GMP) must be applied.

\section{GMP in the Production of Cells for Clinical Therapies}

GMP, a quality assurance system used by pharmaceutical manufacturers, is used in the production of stem cells for clinical application. GMP regulations, first promoted by the US Food and Drug Administration, and implemented in Europe as EU Directive 2003/94/EC [83], underpin the EU Tissue and Cells Directives and the Advanced Therapy Medicinal Products Regulations which pertain to the production of haematopoietic, MSCs, hES and iPS cells for clinical therapy within most of Europe. Within the USA these guidelines have been incorporated into the Good Tissue Practice requirements 
under the Code of Federal Regulations [84, 85]. Internationally, harmonisation of regulation is taking place through the International Conference on Harmonisation of Technical Requirements for Registration of Pharmaceuticals for Human Use (ICH) of which the guidelines ICHQ7 'Good Manufacturing Practice', ICHQ9, 'Quality Risk Management' and ICHQ10 'Pharmaceutical Quality Systems' are particularly relevant [86].

The purpose of GMP is to ensure that these cell-based products are safe, pure and effective, by seeking to control all aspects of the production process from donor selection and harvesting/derivation of the cells, through enrichment/expansion to cell preservation, storage and distribution. It requires traceability throughout the production chain and beyond (through systems for product recall and adverse event reporting) and is predicated on appropriate risk assessment and risk mitigation.

At its most simple, as with haematopoietic stem cells, processing involves mainly volume reduction, preservation and storage. Systems have been developed over the years to manage the risk associated with this form of minimal processing: mainly the avoidance of microbiological contamination and the maintenance of the CD34+ cell population [87-89], and standards have been laid down to ensure that the cells are clinically acceptable [90-91]. However, in cell production processes that involve expansion and banking of cells over periods of weeks and months, the maintenance of conditions that ensure safety and efficacy is particularly onerous, and it is a common misconception that laboratory practices need only be recapitulated by the simple expedient of transferring the process to a cleanroom facility for the cells to be suitable for clinical application. Whilst such facilities are important in the prevention of environmental contamination, all aspects of the process from derivation/isolation of the cells through their maintenance in culture to the preservation, storage and transportation of the cells must be risk assessed for their potential to contribute hazards both microbiologically and non-microbiologically that may affect the safety and efficacy of the cells.

Many of the risks entailed in the banking of stem cells, particularly as they relate to MSCs, hES and iPS cells, are similar to those for any cell culture process. It is well known that cell lines maintained in serial culture are susceptible to genetic variation. The formation of frozen banks of homogeneous cell aliquots can therefore capture a single desired phenotype allowing researchers to share source material containing functionally identical cells that maintain the desired characteristics; making possible direct comparison between studies performed by different research groups or by single researchers over time.

Additionally, the risk of contamination increase when cell lines are maintained for long periods of time in culture. Cell culture medium will readily support the growth of bacteria and fungi and the routine use of antibiotics to suppress growth may have adverse effects on the cells. While such contamina- tion is often readily identified by the turbidity of the culture medium, more subtle forms of contamination such as mycoplasma introduced from the environment; viruses introduced via components of the culture medium and even contamination by other cell lines, are less readily detected and will affect the properties of the cells. Thus, returning periodically to a well characterised, contamination-free, frozen stock of cells reduces the risk of contamination and increases the validity of any results generated from the cell line.

It is not the intention here to review cell culture procedures, the use of xenogeneic components for derivation/isolation/cell expansion, or the risks associated with these; this has been done elsewhere [84, 89, 92-94]. The purpose of this paper is to review cryopreservation, low-temperature storage and transportation of stem cells, particularly as these apply to the embryonic and iPS cell, where there are significant problems both in preservation and compliance with the requirements of GMP.

\section{Cryopreservation of Haematopoietic Stem Cells}

This routine procedure generally involves slow cooling in the presence of a cryoprotectant to avoid the damaging effects of intracellular ice formation. The cryoprotectant in popular use is dimethyl sulphoxide (DMSO), and the use of a controlled rate freezing technique at 1 to $2{ }^{\circ} \mathrm{C} / \mathrm{min}$ and rapid thawing is considered standard [95]. Passive cooling devices that employ mechanical refrigerators, generally at $-80^{\circ} \mathrm{C}$, to cool the cells (so-called dump-freezing) generate cooling rates similar to those adopted in controlled rate freezing. Generally, the outcome from such protocols has been comparable to controlled rate freezing [96-98] though the lack of a freezing record such as that produced by controlled rate cooling machines is problematic from a regulatory perspective.

Whilst the current cryopreservation protocols are clinically effective, questions still remain as to whether or not they are optimal. This is of particular concern in the banking and therapeutic application of cord blood for allogeneic use, where harvested volumes are small and the total number of CD34+ cells/kg body mass is crucial to eventual engraftment in the recipient. Here a number of studies have been undertaken in order to replace the largely empirical approach to developing an optimised protocol with a methodological one that takes into account the sequence of damaging events that occur during the freezing and thawing process $[99,100]$. Such studies have shown that, whilst cooling rates of $1-2.5{ }^{\circ} \mathrm{C} / \mathrm{min}$ are probably optimal for DMSO concentrations of 5-10\%, recovery is likely to be improved if the osmotic damage that occurs through the introduction and removal of the cryoprotectant is tempered by the application of slow addition/elution protocols [101].

DMSO is known to be toxic to tissues and cells, with toxicity being time-, temperature- and concentration-dependent. 
Toxicity varies from cell type to cell type, and the accepted practice has been to introduce the cryoprotectant at low temperatures $\left(+4{ }^{\circ} \mathrm{C}\right)$ for as short a period as is considered practical. However our studies and others have shown that the temperature-dependent toxicity, at the concentrations used in haematopoietic cells cryopreservation, is unlikely to be of practical importance even at ambient temperatures [101, 102].

Adverse reactions in patients receiving cryopreserved haematopoietic stem cells due to the accepted practice of re-infusing the thawed cells without removal of the DMSO are well documented [95], and washing procedures generally based on that originally developed by Rubenstein et al. [103] are in routine use. This protocol, though only employing a two-step elution and washout procedure for DMSO, is carried out in the presence of Dextran. This acts as an osmotic buffer preventing damaging osmotic transients during the removal of the cryoprotectant. The washing procedure also helps to remove granulocyte debris which will also help to reduce adverse reactions in the recipient. Other procedures involving automated cell washing devices have been developed $[95,100]$.

Reduced concentrations of DMSO have also been employed as a means to alleviate adverse reactions where washing procedures were not employed. There seems little adverse effect on cell recovery or engraftment in reducing DMSO concentration to $5 \%$ at optimal cooling rates [101, 104], and concentrations as low as $2 \%$ have been successfully employed [95]. Alternative cryoprotectants such as hydroxethyl starch and trehalose, either in combination with DMSO $[105,106]$ or alone [107], have also been shown to be effective in cryopreserving haematopoietic cells, but only so far in laboratory studies.

\section{Cryopreservation of Mesenchymal Stem Cells}

MSCs from bone marrow and cord blood are cryopreservable by the methods used to cryopreserve their haematopoietic analogues, and slow freezing protocols utilising DMSO as cryoprotectant are in use by many groups [108]. Recent studies by Liu et al. [109] have confirmed that $10 \%$ DMSO and slow cooling / rapid warming does not affect the viability or differentiation potential of adipose-derived MSCs. Adult stem cells derived from human dental pulp also showed high post-thaw recovery and trilineage differentiation potential after slow cooling in 1-1.5 mol/l DMSO ( 7.5-10\%). Furthermore, DMSO was shown to be superior to both ethylene glycol and propylene glycol under these conditions [110].

DMSO is known to have an effect on the epigenetic profile of, and induce differentiation in, murine stem cells $[111,112]$. This, together with its the known adverse reactions when employed as a cryoprotectant for haematopoietic cell therapy, plus its cellular toxicity, have led to attempts to cryopreserve MSCs with other cryoprotectants; either on their own or in combination with DMSO at lowered concentrations. Many of the alternative cryoprotectant formulations have also attempted to remove animal serum from the cryoprotectant solution; both to reduce cost and to improve clinical utility through reducing the likelihood of zoonotic infections in the absence of terminal sterilisation procedures. This has led to substitution with human serum or human serum albumin. However, this too is costly and introduces at least the potential for transmission of human pathogens.

The use of polyvinylpyrrolidone (PVP), an extracellular cryoprotectant, has been investigated as an alternative to cryopreservation with DMSO and foetal calf serum (FCS) [113]. Cellular recovery and differentiation capacity were studied after equilibration in a number of different cryopreservation media followed by 'dump' freezing to $-80{ }^{\circ} \mathrm{C}$ and storage in liquid nitrogen. Recovery of cells cryopreserved in $10 \%$ PVP with human serum was comparable with (though slightly lower than) cells cryopreserved in DMSO with animal serum. A similar study utilising methylcellulose either alone or in conjunction with reduced levels of DMSO indicated that human serum could replace FCS in standard DMSO mixtures without affecting the recovery of cells and that $1 \%$ methylcellulose produced comparable results with DMSO concentrations as low as $2 \%$ when an annexin $\mathrm{V}$ apoptosis assay was used to analyses cells $24 \mathrm{~h}$ post-thaw. Cells also maintained their adipogenic and osteogenic potential [114]. Lui et al. [115] have also adopted a reduced DMSO approach in a recent study to produce a well-defined and xeno-free cryopreservation media for cell therapy with bone marrowderived MSCs. They replaced FCS with combinations of polyethylene glycol (PEG) and trehalose, with DMSO concentration ranging from 2.5 to $7.5 \%$. The recovery, metabolic activity, proliferative capacity and differentiation potential were measured against the standard slow cooling protocol of DMSO and $10 \%$ FCS. Results replacing FCS with PEG in reduced concentrations of DMSO were comparable with those of the control, but this was achieved only in the presence of $2 \%$ bovine serum albumin. Moreover, cryopreservation in $10 \%$ DMSO with $90 \%$ FCS was more effective in their hands than any other combination. Trehalose was ineffective, in contrast to studies on haematopoietic cells derived from cord blood, bone marrow or mobilised peripheral blood where its effectiveness in combination with reduced DMSO concentration has been demonstrated [116, 117]. Nevertheless, these laboratory studies indicate that there is a potential for the development of xeno-free cryoprotectant solutions utilising lowered concentrations of DMSO and slow cooling.

\section{Cryopreservation of Embryonic and Induced Pluripotent Stem Cells}

Whilst both haematopoietic cells and MSCs have proved amenable to cryopreservation by conventional slow cooling protocols, their pluripotent counterparts have been shown to 
be more refractory. In early studies, using a standard slow cooling protocol, Reubinoff et al. [118] reported $16 \%$ recovery after freezing and thawing (as measured by the number of colonies recovered 2 weeks after thawing). The colonies recovered were undersized compared to typical hES cell colonies and showed a significant degree of differentiation. Zhou et al. [119] also reported similar results with only slightly higher recovery (approximately 23\%, based on the number of colonies recovered at day 9, post-thaw). Again, the rate of growth of the surviving colonies was reduced, while the level of differentiation in the surviving colonies was higher than that in a comparable, non-cryopreserved group. Both studies utilised $10 \%$ DMSO as the cryoprotectant and slow cooling at around $1{ }^{\circ} \mathrm{C} / \mathrm{min}$. A study by Ha et al. [120] compared glycerol and ethylene glycol (EG) to DMSO, either on their own or in combination with DMSO. The results indicated that, even with the most favourable combination (5\% DMSO combined with $10 \% \mathrm{EG}$ in $50 \% \mathrm{FCS}$ ) recovery was limited to just $30 \%$. Results from studies by Heng et al. [121] confirmed this apparent failure of embryonic stem cells to survive conventional cryopreservation protocols.

The problem of effective cryopreservation is exacerbated by the 'co-operative' nature of these cells. Unlike adult stem cells, which grow in culture as adherent monolayers of unassociated cells, human (and animal) embryonic stem cells (and iPS cells) will only normally grow in the undifferentiated state as colonies of tightly associated, adherent cells (typically containing between $3 \times 10^{4}$ and $5 \times 10^{4}$ cells per hES cell colony) in co-culture with mitotically inactivated mouse or human fibroblasts as a feeder layer. During cell culture, mammalian cells are sub-cultured by some form of enzymatic dissociation, followed by agitation to remove the cells from the underlying substratum. Dissociation is completed through to a single cell suspension. It is in this form that the cells are passaged or treated with cryoprotectant and cryopreserved.

Mouse embryonic stem cell lines, though colonial in nature, are routinely sub-cultured in this way, and may be successfully cryopreserved as an undifferentiated, single cell suspension [122]. In contrast, hES cells (and primate embryonic stem cells) have not been amenable to passaging or cryopreservation as single cell suspensions. Primate stem cells show an extremely low plating efficiency if dissociated to single cells [123] while re-plating hES cells as a single cell suspension tends to lead to differentiation or cell death. Optimum cell cluster size for cryopreservation has been reported to be in the order of 100-500 cells [124]; though experimental evidence is sparse.

The practical consequence of this, together with the poor results obtained through conventional cryopreservation, led the derivation groups to seek alternative methods of cryopreservation that avoided the damaging effects of slow cooling. This led to the adoption of vitrification as the method of choice for the preservation of embryonic stem cell lines. Whilst this poses some problems for the efficient banking of cell lines for research purposes, there are additional consequences in terms of the application of GMP to this process for cells intended for clinical applications.

\section{Cryopreservation by Vitrification}

During conventional slow cooling, ice forms as a response to the reduction in temperature below the freezing point of the system. The consequences of this are an increase in the solute concentration as water is converted to ice. Both ice and high solute concentration are damaging to cells. Cryoprotectants such as DMSO mitigate these damaging effects by reducing the amount of ice formed at any given sub-zero temperature, thereby limiting the damaging rise in solute concentration. Vitrification approaches the problems associated with ice crystallisation in a different manner. Here cryoprotectants are used in concentrations that prevent ice formation entirely.

Vitrification is the solidification of a liquid without crystallisation and the growth of ice. This is achieved when solutes in the system are sufficiently concentrated, or the system cooled sufficiently rapidly, that the increased viscosity inhibits nucleation and prevents the growth of ice. As cooling continues, viscosity continues to increase until all molecular motion is (for all practical purposes) halted and the solution becomes a glass. In this condition, the system displays the properties of a solid but retains the molecular structure of a liquid [125].

Vitrification may be achieved by increasing the concentration of cryoprotectants to levels sufficient to avoid ice formation whatever the cooling rate. However, this requires the introduction of much higher concentrations of cryoprotectants than are usually tolerated by cells. Chemical toxicity is time-, temperature- and concentration-dependent, and this approach to vitrification has generally required both the careful formulation of multimolar cryoprotectant mixtures, to help lower toxicity and their introduction in a stepwise fashion at increasingly lower temperatures. However osmotic damage is increased by reduction in temperature, and thus any protocol for vitrification using this approach is often a compromise between inflicting chemical toxicity or osmotic damage on the cell. Such an approach has been termed equilibrium vitrification. An alternative approach is non-equilibrium vitrification. This relies on employing extremely high cooling rates in conjunction with lower concentrations of cryoprotectant in order to prevent ice nucleating. However this produces a metastable state that can lead to devitrification (and ice crystallisation) on re-warming. Though this poses serious risks of cell damage, this approach has been successfully applied to many cell and tissues, including embryos, cord blood and amnionderived MSCs [126-128].

The adoption of this method of vitrification as the predominant method of cryopreservation for hES cells is largely due to comparative studies by three groups, two of which indicated rates of recovery of undifferentiated colonies of $>75 \%$ for vitrified hES cells compared to $\sim 5 \%$ after slow cooling $[118,119,129]$. The vitrification protocols reported in these 
studies were very similar, based as they were on that developed for bovine ova and embryos [130] and modified by Reubinoff et al. [118] for application to hES cells. The method has also been described in detail with minor modifications elsewhere [131].

In essence, this protocol requires the stepwise exposure of hESC colony fragments to two vitrification solutions of increasing cryoprotectant concentration, the common components of which are DMSO and EG. The composition of the vehicle solution varies, with differences in sucrose concentration, the presence or absence of serum and the buffer used. Colony fragments are exposed to the two vitrification solutions sequentially. Exposure to the vitrification solutions is brief ( $60 \mathrm{~s}$ and $25 \mathrm{~s}$ respectively at either room temperature or $37^{\circ} \mathrm{C}$ ). No studies have so far been reported to determine the permeability of the cells (or the colony fragments) to either cryoprotectant, or the intrinsic toxicity of these components to hES cells; though studies are underway.

In non-equilibrium vitrification, the higher the cooling rate attained, the lower can be the total cryoprotectant concentration needed and vice versa. Using mixtures of cryoprotectants helps to reduce the intrinsic toxicity of each, and the method published by Reubinoff et al. [118] utilised 20\% DMSO, 20\% EG and $0.5 \mathrm{~mol} / \mathrm{l}$ sucrose. To achieve vitrification using these solutions, very rapid cooling rates were required, though the critical cooling velocity needed to achieve vitrification has not been determined for this solution. Applying the OPS method (for open pulled straw), the high cooling rate was achieved by the direct immersion in liquid nitrogen of finely drawn capillaries holding ultra-small volumes ( $20 \mu \mathrm{l}$ or less) of the vitrification solution containing the colony fragments. Straws were then generally transferred under liquid nitrogen (to avoid devitrification) to liquid-phase nitrogen storage [130,132].

To avoid ice crystallisation during thawing the straws were re-warmed as rapidly as possible by direct immersion of the tip of the loaded straw into pre-warmed culture medium containing sucrose. Once thawed the colony fragments were then expelled into this medium and transferred stepwise through cryoprotectant wash-out solutions, containing decreasing concentration of sucrose as the osmotic buffer, until they were plated into culture medium. An alternative method with direct exposure to growth medium without stepwise elution of the cryoprotectants has also been used with no noticeable deleterious effects [131].

However, vitrification by this technique is technically challenging, and there are anecdotal reports that recovery rates are not as high in practice as those reported in the literature. Even the original paper by Reubinoff et al. [118] reported recovery of $<30 \%$ undifferentiated colonies (a figure not incomparable with those published for slow cooling). The method also suffers from two inherent problems that affect its application in a commercial, GMP setting: scale-up for the production of large banks of cells and the direct exposure of the cells to liquid nitrogen [127].

\section{Vitrification and Scale-Up}

The limitations on sample volume, necessary to achieve the required cooling rates, and the need to vitrify the embryonic stem cells as small clumps of stem cells at best permits the production of only laboratory-scale cell banks by the OPS method. This process is time-consuming, operator-dependent and, with the short exposure times to cryoprotectant, prone to both failure and inconsistency in the final product.

Attempts have been made to address this, at least on a laboratory scale. Heng et al. [133] proposed a design for a culture plate with detachable wells in which whole adherent colonies could be vitrified. Harvesting the hES cell clumps after colony dissociation and passage through a nylon cell strainer, followed by exposure to vitrification solutions and vitrification by direct immersion in liquid nitrogen whilst still retained on the strainer, has been employed by Li et al. [134] for the 'bulk' vitrification of embryonic stem cells. Using this method, the equivalent of a $35 \mathrm{~mm}$ culture dish (approximately $100-150$ cell clumps) could be transferred to a single cell strainer, (equivalent to 10-20 straws) in a procedure taking no more than $5 \mathrm{~min}$. When compared to hES cells recovered by the OPS method, no significant differences were detected in either the rate of re-attachment or in the degree of differentiation (measured at day 7) nor in the pluripotency of the surviving cells. A refinement of this technique, using customised cryovials fitted with stainless steel mesh, produced similar results [135]. Whilst both methods allow for an increase in the quantity of hES cells preserved at any one time, neither method is suitable for automation and commercial scale-up nor do they overcome the potential contamination problems associated with direct exposure to liquid nitrogen.

\section{Vitrification and Contamination}

The transmission of infections through in vitro fertilisation routes has been the subject of a number of reviews [136, 137], and much therein is relevant to embryonic stem cell lines. Moreover, transmission of infection associated with direct exposure to liquid nitrogen has been the source of a number of reports from both laboratory and clinical studies [138, 139]. Though methods and equipment exists and have been validated for the sterile filtration of liquid nitrogen [140], its applicability to cell banking and sterility at the point of use is questionable. Thus current vitrification techniques utilising open straws, followed by their storage under liquid nitrogen is unlikely to be acceptable by regulatory agencies for 'clinical grade' pluripotent stem cell lines.

Methods to separate the vitrification solution from the cryogen have been developed. The simplest of these is the sealed straw used in embryo and gamete cryopreservation. Successful vitrification of hES cell colony fragments has been demonstrated by Richards et al. [129] using sterile $250 \mu \mathrm{l}$ embryo straws which could be sealed using a conventional heat sealer. Such straws have been approved for use by the US Food and 
Drug administration [137]. The results were comparable to the OPS method when comparable volumes (i.e. $20 \mu \mathrm{l}$ ) of hES cell-containing vitrification solution were used. Whilst cooling rates for direct immersion of these straws were not measured, a study by Vajta et al. [130] comparing open, manually pulled straws with conventional $250 \mu \mathrm{l}$ plastic straws indicated that, for similar volumes of vitrification solution, an order of magnitude difference in cooling rate was obtained $(\sim 22,000$ ${ }^{\circ} \mathrm{C} / \mathrm{min}$ vs. $\sim 2,500{ }^{\circ} \mathrm{C} / \mathrm{min}$ ). Whether or not the colony fragments are truly vitrified in the Richards et al. study [129], cooling (and re-warming) is nevertheless sufficiently rapid to afford good rates of recovery.

Whilst the sealed straw prevents contact with potentially contaminating liquid nitrogen during cooling, it does not prevent the possible contamination of the external surface of the straw during handling and storage and its transmission to the thawing and recovery solution. This potential contamination route has been recognised in tissue and haematopoietic stem cell banking and is combated by the use of a secondary container (so called double-bagging). A straw-in-straw method, eliminating this potential route of contamination has been successfully employed for mouse embryos [141] and more recently mouse neurospheres [142]. This technique is likely to cause a further reduction in the cooling (and subsequent rewarming) rate possibly by a further order of magnitude [127]. Thus the cooling rate is unlikely to be sufficiently rapid to sustain vitrification of hES cells in the absence of changes to the composition of the vitrification solutions, and its potential as a closed system for vitrification of human hES and iPS cells has yet to be investigated.

The use of cryovials for vitrification has also been explored. Nishigaki et al. [143] successfully cryopreserved primate embryonic stem and hES cells in a vitrification solution without DMSO. They compared a number of vitrification solutions employing various concentrations of DMSO, EG and PEG with knock-out serum (KSR) replacement in both DMEM and Eurocollins vehicle solutions. Plunge cooling rates for $200 \mu \mathrm{l}$ volumes were measured at $\sim 125^{\circ} \mathrm{C} / \mathrm{min}$. Differential scanning calorimetry (DSC) measurements on the solutions (containing 40\% EG, 10\% PEG and $20 \% \mathrm{KSR}$ ) indicated that the solutions would vitrify at this cooling rate. A re-attachment index was used to assess post-warming recovery after 1 day in culture, and they obtained recovery rates of around $20 \%$ by this method with surviving colonies expressing typical pluripotency markers and the ability to form teratomas.

Another approach to the problem of direct contact between cells and cryogen has been the development of solid surface vitrification. In essence this separates the cryogenic fluid from the samples by using the cryogen to cool a sterile solid surface [144] onto which the microdroplets of vitrification solution containing the cells or tissue are dropped. This method has now been commercialised and used to vitrify murine ovarian tissue and porcine blastocysts [145, 146].
Whilst these methods address the problems associated with potential contamination via the cryogen and other methods have increased the through-put of material that can be vitrified, no method combines both of these requirements nor lends itself to scale-up or automation. At best the sealed straw and straw-in-straw methods may provide a means, acceptable to the regulatory authorities, for small-scale cell banking of seed stocks of stems cells for therapeutic application. For these and for other logistical reasons, the cryopreservation method for clinical applications is most likely to involve conventional slow cooling methodologies despite their apparent problems.

\section{Cryopreservation by Conventional Slow Cooling}

As already discussed the early studies on cryopreserving hES cell lines using slow cooling techniques and DMSO with varying concentrations of serum were discouraging [118-121, 129]. These studies all employed protocols previously effective for murine embryonic stem (mES) cell lines which in turn had been adapted from conventional slow cooling protocols for cultures cells [147]. Unlike hES cells, when applied to mES cells, recovery after thawing was typically in excess of $90 \%$ with surviving cells showing low rates of differentiation and high rates of proliferation whilst still retaining their pluripotent capacity.

These early comparative studies made little attempt to control or investigate any of the cryobiological variables associated with damage during slow cooling: cooling rate, cryoprotectant concentration, osmotic effects associated with the introduction and removal of the cryoprotectant, or, in a system where the cellular material is frozen as an agglomeration of cells requiring maintenance of cell-to-cell contact, ice nucleation. The problems were (and continue to be) exacerbated by the necessity to apply suitable assays to measure not only immediate post-thaw recovery in cell clumps of varying and undefined size, but also the ability of these agglomerates to re-attach, proliferate and maintain pluripotency for extended periods in culture and the n-points at which these assays are applied [148]. Comparison of studies on both vitrification and/or slow cooling is therefore often difficult, and the importance placed on evidence of pluripotency and karyotypic stability as indicators of the effectiveness of the cryopreservation procedure is perhaps overemphasised. Such tests are generally carried out after a number of days or weeks in culture where the effects of sub-lethal injury will have been diluted out [149].

Though no studies have adopted a methodological approach similar to that employed for haematopoietic $[99,104]$ or mES cells [150], a number of more recent studies have attempted to investigate some of the cryobiological variables. These studies have indicated that control of the cryobiological variables can significantly improve the recovery of embryonic stem cells preserved by slow cooling. In the first of these studies, Ware et al. [151] investigated the effect of seeding on the 
survival of a range of hES cell lines after thawing. Survival was calculated as combined colony number / colony size, relative to a pre-freeze control. Clusters were frozen by controlled rate cooling in $10 \%$ DMSO at cooling rates between 0.3 and $3{ }^{\circ} \mathrm{C} / \mathrm{min}$. High survival $(\sim 80 \%)$ was obtained at cooling rates below $1.8^{\circ} \mathrm{C} / \mathrm{min}$, but only if the samples were seeded. The effect of seeding temperature on survival was not fully investigated; however, seeding at -7 and $-10^{\circ} \mathrm{C}$ produced similar results. Yang et al. [152] have reported similar results with seeding at $-10{ }^{\circ} \mathrm{C}$ and a cooling rate of $0.5^{\circ} \mathrm{C} / \mathrm{min}$.

Valbuena et al. [153] investigated the effect of stepwise addition of $2 \mathrm{~mol} / \mathrm{l} \mathrm{DMSO}$ in a four-step addition process at room temperature on hES cells. These were then subjected either to passive cooling at $-80{ }^{\circ} \mathrm{C}$ overnight or two-step cooling without seeding. Though immediate post-thaw survival was low $(\sim 10 \%)$, it was comparable in the cell lines studied to cells vitrified by the OPS and sealed straw methods. More recent and encouraging studies have emphasised the beneficial effects of stepwise equilibration of the cryoprotectant and seeding during slow cooling. Li et al. [154] obtained re-attachment and recovery rates of over $50 \%$ using programmed cooling $\left(1{ }^{\circ} \mathrm{C} / \mathrm{min}\right)$ with seeding at $-7^{\circ} \mathrm{C}$ after single-step addition of the cryoprotectant (10\% DMSO) with comparatively low survival in the group cryopreserved without seeding. A similar study [155] including two-step equilibration of the cryoprotectant also demonstrated improved recovery after seeding at $-7{ }^{\circ} \mathrm{C}(>50 \%)$ as well as highlighting another possible confounding factor: variability in the cell line response to slow cooling injury. In this study two genetically modified embryonic stem cells lines were separated into four groups depending on method of cryoprotectant addition and presence or absence of a seeding event in the slow cooling programme. In all groups one of the two lines consistently exhibited an approximately $50 \%$ lower level of recovery than the other. In the group cryopreserved by single-step addition of cryoprotectant and no seeding, results were comparable to those obtained in many of the other studies $(\sim 5 \%)$. At this level of recovery it is difficult to effectively demonstrate differences that could be attributable to the cell line itself and, since the difference is likely to be attributable to the cells osmotic response to cryoprotectant exposure, would not have been visible in many of the early studies.

In a multifactorial study using Rhesus Macaque embryonic stem cells, Baran and Ware [156] demonstrated firstly the superiority of DMSO over EG or a mixture of EG and DMSO, secondly an optimum cooling rate of around $1{ }^{\circ} \mathrm{C} / \mathrm{min}$ (compared to $0.3{ }^{\circ} \mathrm{C} / \mathrm{min}$ or plunge freezing in $10 \% \mathrm{DMSO}$ ), and, lastly, an effect of both warming rate and post-thaw exposure to DMSO at $37^{\circ} \mathrm{C}$ (equivalent to thermal runaway) on the survival after freezing. This study did not investigate the effect of stepwise equilibration but did again demonstrate that controlled-rate cooling with the induction of ice nucleation could increase post-thaw survival dramatically, from $<22$ to $>90 \%$, at least in this primate stem cell line.

\section{Mechanisms of Slow Cooling Injury}

The basic principles and damaging events that can underlie slow cooling injury have been well documented [157]. Cryoprotectant toxicity, osmotic damage during exposure to and removal of cryoprotectants, and so-called solution effect injury from the high solute concentrations to which the cells are exposed during freezing are just some of the damaging events that may occur. No systematic studies have yet been undertaken in the context of hES cells; however there is evidence of the protective effect of seeding to control ice formation within the system.

During slow cooling of a cell suspension, ice nucleation will generally be initiated in the extracellular compartment with cells inhabiting the solute channels that form between the growing ice crystals. Where nucleation has occurred within a cell, intracellular ice will form but this event will not affect neighbouring cells. In a cluster of cells such an event may have more profound consequences. Cell-to-cell propagation of intracellular ice has been demonstrated in cultured cell monolayers [158] and cell strands from insect salivary glands [159]. It has been postulated that this occurs via gap junctions, and there is experimental evidence to support this. Acker et al. [160] compared ice propagation in MDCK (gap junction forming) and V-79W (non-gap junction-forming) cell monolayers and observed a significant difference in the formation and propagation of intracellular ice in confluent monolayers with and without gap junctions. Cooling rates employed in this study were in the order of $25^{\circ} \mathrm{C} / \mathrm{min}$; however an increase in the incidence of cell damage, attributed to the damaging effect of ice nucleation in cell monolayers compared to single cell suspensions, has been reported for corneal keratinocytes at $1{ }^{\circ} \mathrm{C} / \mathrm{min}$ [161].

The presence of functional gap junctions has been demonstrated in hES cells $[162,163]$, and gap junction communication has been implicated in a number of cellular processes including cell proliferation, differentiation and apoptosis [164, 165], leading to speculation that these structures contribute to paracrine signalling between hES cells and are essential for survival and control of the undifferentiated state [42, 43, 124]; control that is disrupted if gap junctions are disrupted by passaging as single cell suspensions or cryopreservation. The observation that intracellular ice propagates more readily between cells with gap junctions under certain conditions may at least in part explain the poor recovery of hES cells after slow cooling. Damage to the hESC clusters caused by intercellular ice propagation, either by random nucleation events within the cluster and propagation through the gap junctions [166] or from surface-catalysed nucleation at its periphery [167] followed by cell-to-cell propagation, could lead to disruption of the cell cluster affecting cell proliferation, differentiation and apoptosis on thawing [159]. Methods that attempt to control the nucleation event, such as seeding, may therefore act to initiate ice formation outside of the cellular (or cell cluster) compartment. 
Modification to the environment in which the cells experience the freezing process also appears to modify the extent of cellular injury. Ji et al. [168] compared whole colonies frozen in suspension with colonies frozen whilst still adherent to the culture surface with only a thin layer of cryoprotectant covering the cell layer. Survival in both cases was low $(<10 \%)$. However when the adherent cells were embedded within a layer of Matrigel (a laminin-based basement membrane matrix for anchorage-dependent cells), immediate post-thaw viability was increased. Subsequent re-plating gave a higher incidence of re-attachment and a lower incidence of differentiation compared to colonies frozen in suspension or frozen adherent but un-encapsulated, perhaps through preferential formation of ice in the encapsulating matrix.

Apoptosis in response to low temperature exposure is well documented [169], and the involvement of apoptotic cell death in cryopreservation injury has been reported in a wide variety of cell types including haematopoietic stem cells [170]. Heng et al. [171] postulated the involvement of apoptosis in early cell death in hES cells cryopreserved by slow cooling after observing that cell viability immediately post-thaw (as measured by trypan blue dye exclusion) was initially very high but showed a gradual reduction with time in culture at $37^{\circ} \mathrm{C}$. Moreover this loss of viability could be reversibly slowed by a reduction in the temperature at which the cells were held post-thaw [172], indicating an apoptotic mechanism for cell death rather than an unregulated necrotic process. The role of cryopreservation in activating both the extrinsic and intrinsic pathways of apoptosis was recently investigated by Xu et al. [173]. They examined the effect of DMSO exposure and slow cooling on the production of reactive oxygen species (ROS), p53 levels, levels of the initiators of the apoptotic cascade (caspases 8 and 9) and cytoskeletal F-actin (which can contribute to the induction of apoptosis in response to environmental changes). Propidium iodide (PI) / annexin V FITC staining by FACS $2 \mathrm{~h}$ postthaw was used to assess initial viability and early apoptosis. PIpositive cells accounted for approximately $20 \%$ of the cell population with another $30 \%$ exhibiting early-stage apoptosis (PI-negative, annexin V-positive). Exposure to DMSO had no effect on the level of hydrogen peroxide or superoxide anion generation, however there were significant increases in these following freezing and thawing. They concluded that elevation of ROS led to the activation and translocation of p53 as strong expression of this protein was seen in the nucleus of postthawed cells. This in turn led to activation of caspase- 9 which was also significantly increased after thawing. Caspase- 8 activity also showed a similar increase post-thaw, indicating the possible activation of the extrinsic pathway.

Caspase inhibitors significantly reduced caspase activity, but this did not appear to effect an improvement in post-thaw recovery, in contrast to other studies [174]. Addition of an inhibitor of Bax (a pro-apoptotic protein regulating mitochondrial membrane permeability) did however improve post-thaw recovery though not to the same extent as either the Rho kinase
(ROCK) inhibitor Y-27632 or ROCK plus a p53 inhibitor (pifithrin- $\mu$ ). The inhibition by ROCK of both caspase- 8 and caspase- 9 activity led them to the conclusion that cryopreservation activated both the extrinsic and intrinsic apoptotic pathways in hES cells; though the particular sensitivity of hES cells to apoptosis as compared to mES cells remains unanswered, even though both show similar sensitivities to ROS (which requires the addition of an antioxidant to their routine culture medium).

\section{Rho-Associated Kinase (ROCK) Inhibitors and the Survival of Stem Cells}

Rho kinases are proteins which have been shown to play a significant role in an array of cellular processes, including adhesion, proliferation, differentiation and apoptosis depending on the cell type [175]. The ROCK inhibitors Y-27632 and fasudil were first shown to markedly reduce dissociation-induced apoptosis in hES cells by Watanabi et al. [176] when these cells were dissociated to single cell suspensions prior to passaging. However, their exact mode of action in hES cells is a matter of some debate. It has been suggested that instead of blocking apoptotic pathways, ROCK inhibitors counteract anoikis (detachment-induced apoptosis) or enhance cell-cell interactions through modulation of gap junctions thereby increasing the adhesive properties of the cells and enhancing post-dissociation aggregation $[177,178]$. Whatever the mode of action, ROCK inhibitors have been shown to improve postthaw survival in a number of studies. Li et al. [179] first demonstrated that Y-27632 added to the post-thaw culture medium for $24 \mathrm{~h}$ post-thaw increased hES cell survival rate 10fold, with colony growth rates similar to unfrozen controls.

Studies by Martin-Ibanez et al. [180] replicated this initial finding. Addition of the inhibitor Y-27632 to the cryopreservation medium alone did not provide any statistically significant improvement compared to cells frozen in the absence of the inhibitor. However, they too demonstrated a beneficial effect of its inclusion post-thaw. Furthermore, addition to both the preservation solution and post-thaw culture medium further improved survival; with hES cell colonies exhibiting low levels of differentiation. They also measured Oct-4 levels and the canonical pluripotency markers. Cells displayed pluripotency markers at day 1 post-thaw and Oct-4 levels, as measured by RT-PCR, were comparable to non-frozen controls at all post-thaw time points.

The effect of ROCK inhibitor Y-27632 has now been shown to have similar effects on the recovery from cryopreservation of both adult stem cells and bone marrow-derived MSCs as well as human iPS cells in both feeder-associated and feeder-free conditions [181-184] and protocols for the cryopreservation of dissociated hES cells have recently been published $[185,186]$.

\section{Other Additives and Alternative Cryoprotectants}

Alternatives to DMSO as the cryoprotectant of choice for stem cells have been driven in non-embryonic stem cells 
largely by the adverse reactions caused in patients. In hES cells the motivation has been the known effect of this solvent on inducing differentiation [187]. However the minimum concentration $(0.125 \%)$ and exposure time (days) required for it to exert an effect are likely to be of importance only in toxicological studies utilising hES cells, and not in the hES cell culture or cell banking.

Cryopreservation using the non-permeating disaccharide trehalose has been compared with slow cooling in $10 \%$ DMSO and serum [168]. Trehalose does not readily penetrate cells, with only low concentrations $(<0.5 \%)$ being absorbed by passive diffusion or active endocytotic mechanisms. Cells were exposed to the trehalose loading medium for $24 \mathrm{~h}$ prior to exposure to the standard cryoprotectant mixture $(10 \%$ DMSO and serum). There was a small but statistically significant increase in post-thaw survival of adherent colonies compared to DMSO serum without trehalose but only where the serum concentration in the cryoprotectant medium exceeded $50 \%$. Wu et al. [188] also utilised trehalose. They showed a beneficial effect of trehalose in the elution solution, suggesting its mode of action as an osmotic buffer, and in the freezing medium (without a pre-incubation), suggesting that the trehalose was acting as an extracellular cryoprotectant.

Polyampholytes (polyelectrolytes bearing both cationic and anionic repeat group) such as poly-L-lysine have been used successfully to cryopreserve rat MSCs [189] and may offer an alternative to DMSO. They offer the advantage of also being antifreeze proteins that may help to control or reduce ice crystallisation. Sericin (a protein derived from the silkworm) has been shown to accelerate cell proliferation in hybridoma cell lines [190] and improve the attachment of cryopreserved hepatocytes, when used as a replacement for serum in a DMSO-based cryoprotectant with maltose [191].

Antioxidants in the form of $\beta$-mercaptoethanol are routinely present in the culture medium of hES cells but the overproduction of ROS during cryopreservation has led to the addition of antioxidants to the freezing solution in an attempt to reduce damage. Adding glutathione to the cryoprotectant and the post-thaw recovery solution has been shown to improve the survival of embryonic stem cells following cryopreservation [192].

\section{Commercial Cryoprotectant Solutions}

The drive towards clinical applications has led to the reappraisal of both the conditions under which cell lines are derived and the components that make up both culture media and freezing solutions [193, 194]. Moreover, xeno-free culture media (albeit still containing human serum albumin) have been formulated [195]. A wide range of commercially available cryoprotectant solutions are available [196], including CE marked DMSO, many of which will be suitable for clinical application. Commercial preparations have a number of advantages from a GMP perspective in that they will be sterile and batch tested; though not all will have been certified for other than in vitro use. In the tissue banking area in the UK, regulatory agencies require, at a minimum, that the cryoprotectant is a sterile formulation, and the use of CE marked, sterile DMSO is required.

Commercially available cryoprotectants therefore have the advantage over in-house preparations in that extensive sterility and endotoxin testing will have already been carried out. The use of commercially available freezing and post-thaw washing solutions has been reported for hES and iPS cells [197]. A proprietary solution (STEM-CELLBANKER ${ }^{\mathrm{TM}}$ ) was compared to a standard freezing procedure with $10 \%$ DMSO. The commercially available cryoprotectant is a mixture of DMSO, glucose and a high molecular weight polymer (undisclosed) in phosphate-buffered saline. Post-thaw recover was substantially increased without any detrimental impact on proliferation or differentiation, and the freezing protocol could be combined with protocols for derivation and culture in xeno-free conditions, making the cell lines suitable for clinical application.

The fact that at least one component is undisclosed however highlights a potential problem in the use of commercial formulations: that of disclosure. For human application, a risk assessment which includes the components of culture and freezing solutions must be undertaken to assure that adverse events attributable to these solutions are avoided. The use of proprietary solutions in which not all components are declared poses risks. However, the use of confidentiality agreements with the manufacturer permitting disclosure may mitigate this risk.

\section{Scale-Up}

Automated culture systems for large-scale production of stem cells are already available $[198,199]$, and much research is underway to translate laboratory-based cell culture protocols to automated systems; however cryopreservation procedures lag behind. The problems experienced with conventional cryopreservation protocols and the use of straws have undoubtedly contributed to this. Nevertheless novel systems allowing scaleup and cryopreservation have recently been reported in the literature, and some of these are commercially available.

Expansion of hES cells on microcarrier beads in stirred culture systems with conventional cryopreservation of bead-adherent hES cell colonies has been reported [200]. Recovery of hES cells, frozen on feeder cell-seeded microcarriers, was compared with hES cells frozen as freely suspended colonies. A 1.5- to 2-fold increase in recovery was observed, and the cells remained undifferentiated in culture post-thaw.

A commercially available, gas-permeable cassette system for scale-up has also been developed. These ported cassettes are compatible with DMSO (at least in the concentrations used in cryopreservation) and with storage under vapourphase liquid nitrogen. Since they are gas permeable, the cassettes can be used for the culture of hES cells, and hES cell colonies can be cryopreserved in situ by the simple expedient 
of changing the culture media for the cryoprotectant [201]. In the study using these cassettes, cells were cryopreserved by passive cooling in 10\% DMSO and serum. Even under these conditions proliferation ratios, relative to colony fragments cryopreserved in suspension in cryovials, were in the order of 20- to 200 -fold greater.

Cryopreservation of mammalian cell lines in cryocyte bags has been reported [202], but the cassette system which allows the manipulation of solutions through sealable ports (and is thus similar in principle to systems used for haematopoietic stem cell preservation) would be a suitable for double bagging and controlled rate cooling.

The use of controlled rate cooling machines within a clean room environment is a potential source of contamination as the nitrogen gas used to cool the samples is vented into the clean room. Cells are thus usually transported out of this environment for freezing. This can lead to potential delays and may contribute to cryoprotectant toxicity if delays are lengthy. Recently, controlled rate cooling devices suitable for use within a cleanroom environment have become available and have been used to freeze embryonic stem cells [203].

\section{Low Temperature Storage and Transportation}

The problem associated with low temperature storage and transportation from a GMP perspective is mainly two-fold: maintenance of a suitably low temperature and prevention of contamination.

\section{Storage Temperature}

Whilst the therapeutic products of stem cells may not require extended periods of storage, the master and working cell banks from which the products will be derived are likely to require long-term storage. This will require the storage at least below the glass transition temperature required to arrest molecular processes. This has generally been achieved by storage in the liquid or vapour phase of liquid nitrogen. Mechanical refrigeration, delivering stable temperatures below $-135^{\circ} \mathrm{C}$, is now reliable, and studies on stem cells indicate no significant differences between this and liquid nitrogen at least in the medium term - up to 5 years [204]. In some systems, temperature fluctuations around the glass transition can be damaging [205], and the storage of vitrified stem cell material at these temperatures, with the possibility of devitrification and ice crystal formation, is probably ill-advised.

Traditionally, storage at ultra-low temperatures was undertaken by immersing the product in liquid nitrogen to ensure as stable a temperature as possible. Following an outbreak of hepatitis in the 1990s in the UK, which was traced to contamination of stem cell harvests during storage under liquid nitrogen [138], this practice was questioned at least for clinically relevant material, and the practice has largely changed to storage in liquid nitrogen vapour (or more accurately gas) phase; a practice also recommended for gametes and embryos [206]. The argument against vapour phase storage, particularly for vitrified material, is that storage vessels designed for under-liquid storage show a considerable vertical temperature gradient when combined with vapour phase platforms. Temperatures as high as $-100{ }^{\circ} \mathrm{C}$ have been recorded at the top of the inventory system in such vessels. However, a number of technical solutions to this, some designed to be retro-fitted to older storage vessels, have been developed.

The simplest of these is the heat shunt. Made either by standing a thermally conducting material such as an aluminium racking system in the liquid present in the base of the vessel [207] or by immersing a copper cooling fin into the liquid [208], the temperature gradient can be dramatically reduced giving temperatures under the lid of the liquid nitrogen storage refrigerator of below $-160{ }^{\circ} \mathrm{C}$. Changes to the design of liquid nitrogen storage refrigerators, with the introduction of 'isothermal' or 'dry' vessels, (which have liquid nitrogen-jacketed storage compartments) and vessels which are almost completely vacuum insulated have reduced temperature differentials between the bottom and the top of the vessel even more; storage temperature below $-180{ }^{\circ} \mathrm{C}$ can now be expected even at the top of the inventory system. From a GMP perspective, continuous temperature monitoring and alarming of the storage system is an absolute requirement.

\section{Contamination}

The risk of contamination of cell products during low temperature storage are mainly those associated with storage under liquid nitrogen. Vapour phase storage largely overcomes this problem, and experimental studies evaluating the potential for cross-contamination confirmed this [209]. However, the products are still in contact with the external environment and the potential for contamination exists. In haematopoietic stem cell preservation, secondary systems (double bags) are used to protect the primary container. However such systems do not exist currently for non-haematopoietic stem cells. From this point of view, the use of open straws, such as those used to vitrify hES cells, presents problems and is unlikely to be approved by regulatory authorities.

As conventional cryopreservation protocols for slow cooling are improved, the use of cryovials again becomes a realistic possibility. Currently, most cryovials do not prevent the ingress of liquid nitrogen and are therefore potentially open to contamination. Partial sealing of cryovials has been accomplished with heat-sealable membranes [210], and novel closed system cryovials are under development. Recently, the use of pharmaceutical grade plastic cryovials, currently being used to deliver biological therapeutics such as monoclonal antibodies, was evaluated for use in the cryopreservation and storage of cell therapy products including MSCs [211]. The vials were found to be suitable for low temperature storage and transportation of MSCs as well as for use in automated filling systems. 


\section{Low Temperature Transportation}

For non-vitrified material transportation on pellets of solid $\mathrm{CO}_{2}$ is the accepted practice. From a regulatory perspective, the containers used for transportation should be validated and the environment within the containers temperature monitored. This may be by individual temperature logging devices or by the use of chemicals which act as thermal exposure indicators, or other devices.

To avoid devitrification, vitrified cells should be transported in liquid nitrogen dry shippers. These come in a range of sizes from those suitable for use internally within a laboratory or cell bank to those for transporting cells over long distances. They function by retaining liquid nitrogen within a molecular sieve-like material which absorbs the liquid nitrogen and permits storage at liquid nitrogen temperatures for up to 14 days. All require charging with liquid nitrogen before use. For compliance with GMP these too need to be validated and periodically re-inspected to ensure that they retain their thermal properties. Data logging lids which monitor and record dry shipper temperature during transportation are available for these containers. Potential contamination and subsequent decontamination are issues for these containers since they are used and re-used many times. Recent studies investigating the potential for contamination have shown that dry shippers do not pose a cross-contamination threat in the absence of damage to the shipment [212] and that if contamination of the shipper does occur they are amenable to decontamination with the method of decontamination dependent on the type of absorbent used to hold the liquid nitrogen [213].

\section{Conclusion}

Cryopreservation is a small part of the process of producing stem cells and their derivatives for therapy. While the process is routine for haematopoietic stem cells and largely worked out for MSCs, at least for autologous use, cryopreservation of hES and iPS cells is only now really being explored. The improvement in conventional slow cooling protocols and the novel container systems being developed are likely to provide systems that are compatible with the requirements of GMP, regulation, automation, and scale-up. However, the research being undertaken is still empirically based, and sound methodological approaches to optimising cryobiological variables are still required if the maximum benefits for regenerative medicine therapies are to be realised.

\section{Disclosure Statement}

The author declared no conflict of interest.

\section{References}

1 Mathe G, Jammet H, Pendic B, Schwarzenberg L, Duplan JF, Maupin B, Lataret R, Larriue MJ Kalic D, Djukic Z: Transfusion and grafts of homologous bone marrow in humans after accidental high dose irradiation. Rev Fr Etud Clin Biol 1959; 4:226-238.

2 Mathe, G, Bernard J, Schwarzenberg L, , Larriue MJ, Lalanne CM, Dutrieux A, Denoix PF, Surmont J, Schwarzmann V, Ceoara, B: Trial treatment of patients afflicted with acute leukemia in remission with total irradiation followed by homologous bone marrow infusion. Rev Fr Etud Clin Biol 1959;4:675-704.

$\checkmark 3$ Gatti RA, Meuwissen HJ, Allen HD, Hong R, Good RA: Immunological reconstitution of sexlinked lymphopenic immunological deficiency. Lancet 1968;2(7583):1366-1369.

4 Bach FH, Albertini RJ, Joo P, Anderson JL, Bortin MM: Bone-marrow transplantation in a patient with the Wiskott-Aldrich syndrome. Lancet 1968; 2(7583):1364-1366.

$\checkmark 5$ Gluckman E, Broxmeyer HA, Auerbach AD, Friedman HS, Douglas GW, Devergie A, Esperou H, Theirry D, Socie G, Lehn P, Cooper S, English D, Kurtzberg J, Bard J, Boyse EA: Hematopoietic reconstitution in a patient with Fanconi's anemia by means of umbilical-cord blood from an HLAmatched identical sibling. N Engl J Med 1989;321: 1174-1178.

6 Harris DT: Non-haematological uses of cord blood stem cells. Br J Haematol 2009;147:177-184.

Cryopreservation of Human Stem Cells for

Clinical Application
7 Malgieri A, Kantzari E, Patrizi MP, Gambardella $\mathrm{S}$ : Bone marrow and umbilical cord blood human mesenchymal stem cells: state of the art. Int J Clin Exp Med 2010;3:248-269.

8 Gratwohl A, Baldomero H, Aljurf M, Pasquini MC, Bouzas LF, Yoshimi A, Szer J, Lipton, J, Schwendener A, Gratwohl M, Frauendorfer K, Neiderwieser D, Horowitz M, Kodera Y: Haematopoietic stem cell transplantation a global perspective. JAMA 2010;303:1617-1624.

9 Gratwohl A, Baldomero H, Schwendener A, Gratwohl M, Apperley J, Frauendorfer K, Neiderwieser D: The EBMT activity survey 2008 impact of team size, team density and new trends. Bone Marrow Transplant 2011;46:174-191.

10 Friedenstein AJ, Gorskaja JF, Kalagina NN: Fibroblast precursors in normal and irradiated mouse hematopoietic organs. Exp Haematol 1976;4:267-274.

11 Lindner U, Kramer J, Rohwedel J, Schlenke P: Mesenchymal stem or stromal cells towards a better understanding of their biology. Transfus Med Hemother 2010;37:75-83.

12 Zvaifler NJ, Marinova-Mutafchieva L, Adams G, Edwards CJ, Moss J Burger JA, Maini RN: Mesenchymal precursor cells in the blood of normal individuals. Arthritis Res 2000;2:477-488.

13 Erices A, Conget P, Minguell JJ: Mesenchymal progenitors in human cord blood. Br J Haematol 2000;109:235-242.

14 Igura K, Zhang X, Takahashi K, Mitsuru A, Yamaguchi S, Takashi TA: Isolation and characterisation of mesenchymal progenitor cells from chorionic villi of human placenta. Cytotherapy 2004;6:543-553.
15 Tsai MS, Lee JL, Chang YJ, Hwang SM: Isolation of human multipotent mesenchymal stem cells from second trimester amniotic fluid using a novel two-stage culture protocol. Human Reprod 2004; 19:1450-1456.

16 Miki T, Lehmann T, Cai H, Stolz DB, Strom SC: Stem cell characteristics of amniotic epithelial cells. Stem Cells 2005;23:1549-1559.

17 Gronthos S, Mankani M, Brahim J, Robey PG, Shi S: Postnatal human dental pulp (DPSCs) in vitro and in vivo. Proc Natl Acad Sci U S A 2000;97: 13625-13630.

18 Miura M, Gronthos S, Zhao M, Lu B, Fisher LW, Robey PG, Shi S: SHED - stem cells from human exfoliated deciduous teeth. Proc Natl Acad Sci U S A 2003;100:5807-5812.

19 Zuk PA, Zhu M, Ashjian P, De Ugarte DA, Huang JI, Mizuno H, Alfonso ZC, Fraser JK Benheim P, Hedrick MH: Human adipose tissue is a source of multipotent stem cells. Mol Biol Cell 2002;13:42794295.

20 Fibbe WE, Noort WA: Mesenchymal stem cells and haematopoietic stem cell transplantation. Ann N Y Acad Sci 2003;996:235-244.

21 Strem BM, Hicok KC, Zhu M, Wulur I, Alfonso Z, Schreiber RE, Fraser JK, Hedrick MH: Multipotent differentiation of adipose tissue-derived stem cells. Keio J Med 2005;54:132-141.

22 Sarugaser R, Lickorish D, Baksh D, Hosseini MM, Davies JE: Human umbilical cord perivascular (HUCPV) cells - a source of mesenchymal progenitors. Stem Cells 2005;23;220-229. 
23 Sarugaser R, Hanoun L, Keating A, Stanford WL, Davies JE: Human mesenchymal stem cells self-renew and differentiate according to a deterministic hierarchy. PLoS ONE 2009;4:e6498.

24 Grove JE, Bruscia E, Krause DS: Plasticity of bone marrow-derived stem cells. Stem Cells 2004;22:487500

25 Makino S, Fukuda K, Miyoshi S, Konishi F, Kodama H, Pan j, Sano M, Takahashi T, Hori S, Abe H, Hata J, Umezawa A, Ogawa S: Cardiomyocytes can be generated from marrow stromal cells in vitro. J Clin Invest 1999;103:697-705.

26 Ong SY, Dai H, Leong KW: Inducing hepatic differentiation of human mesenchymal stem cells in pellet cuture. Biomaterials 2006;27:4087-4097.

$\checkmark 27$ Dezawa M, Kanno H, Hoshino M, Cho H, Matsumoto N, Itokazu Y, Tajima N, Yamada H, Sawada H, Ishikawa H, Mimura T, Kitada M, Suzuki Y, Ide C: Specific induction of neuronal cells from bone marrow stromal cells and application for autologous transplantation. J. Clin Invest 2004;113: 1701-1710.

28 Urbich C, Dimmeler S: Endothelial progenitor cells functional characterization. Trends Cardiovasc Med 2004;14:318-322.

29 Bai K, Huang Y, Jia X, Fan Y, Wang W: Endothelium oriented differentiation of bone marrow mesenchymal stem cells under chemical and mechanical stimulation. J Biomech 2010;19:1176-1181.

-30 Terada N, Hamazaki T, Oka M, Hoki M, Mastalerz DM, Nakano Y, Meyer EM, Morel L, Petersen BE, Scott EW: Bone Marrow Cells adopt the phenotype of other cells by spontaneous cell fusion. $\mathrm{Na}$ ture 2002;416:542-545.

-31 Ying QL, Nichols J, Evans EP, Smith AG: Changing potency by spontaneous fusion. Nature 2002; 416:485-487.

32 Kuroda Y, Kitada M, Wakao S, Nishikawa K, Tanimura Y, Makinoshima H, Goda M, Akashi H, Inutsuka A, Niwa A, Shigemoto T, Nabeshima Y, Nakahata T, Nabeshima Y, Fujiyoshi Y, Dezawa M: Unique multipotent cells in adult human mesenchymal cell populations. Proc Natl Acad Sci U S A 2010;107:8639-8643.

-33 Kögler G, Sensken S, Airey JA, Trapp T, Müschen M, Feldhahn N, Liedtke S, Sorg RV, Fischer J, Rosenbaum C, Greschat S, Knipper A, Bender J, Degistirici O, Gao J, Caplan AI, Colletti EJ, Almeida-Porada G, Müller HW, Zanjani E, Wernet P: A new human somatic stem cell from placental cord blood with intrinsic pluripotent differentiation potential. J Exp Med 2004;200:123-135.

>34 Santourlidis S, Wernet P, Ghanjati F, Graffmann N, Springer J, Kriegs C, Zhao X, Brands J, AraúzoBravo MJ, Neves R, Koegler G, Uhrberg M: Unrestricted somatic stem cells (USSC) for umbilical cord blood display uncommitted epigenetic signature of the major stem cell pluripotency genes. Stem Cell Res 2011;6:60-69.

-35 Reinisch A, Bartmann C, Rohde E, Schallmoser K, bjelic-Radisic V, Lanzer G, Linkesch W, Strunk D: Humanized system to propagate cord blood-derived multipotent mesenchymal stromal cells for clinical application. Regen Med 2007;2:371-382.

\36 Banfi A, Muraglia A, Dozin B, Mastrogiacomo M, Cancedda R, Quarto R: Proliferation kinetics and differentiation potential of ex vivo expanded human bone marrow stromal cells; implications for their use in therapy. Exp Hematol 2000;28:707-715.

37 Bonab MM, Alimoghaddam K, Talebian F, Ghaffari SH, Ghavamzadeh A, Nikbin B: Aging of mesenchymal stem cells in vitro. BMC Cell Biol 2006;7:14.
38 Dominici M, Le Blanc K, Mueller I, Slaper-Cortenbach I, Marini F, Krause D, Deans R, Keating A, Prockop Dj, Horwitz E: Minimal criteria for defining multipotent mesenchymal stromal cells. The International Society for Cellular Therapy position statement. Cytotherapy 2006;8:315-317.

39 Barry FP, Murphy JM: Mesenchymal stem cells: clinical applications and biological characterisation. Int J Biochem Cell Biol 2004;36:568-584.

40 Schaffler A, Buchler C: Concise review: adipose tissue-dervived stromal cells - basic and clinical implications for novel cell-based therapies. Stem Cells 2007;25:818-827.

41 Bongso A, Fong C-Y, Ng SC, Ratnam S: Isolation and culture of inner mass cells from human blastocysts. Hum Reprod 1994;9:2110-2117.

42 Thomson J, Itskovitz-Eldor J, Shapiro, SS, Waknitz MA, Swiergeil JJ, Marshall VS, Jones JM: Embryonic stem cell lines derived from human blastocysts. Science 1998;282:1145-1147.

43 Reubinoff BE, Pera MF, Fong C-Y, Trounson A, Bongso A: Embryonic stem cell lines from human blastocyts: somatic differentiation in vitro. Nat Biotechnol 2000;18: 399-404.

44 Strelchenko N, Verlinsky O, Kukharenko V, Verlinsky Y: Morula-derived human embryonic stem cells. Reprod Biomed Online 2004;9:623-629.

45 Klimanskaya I, Chung Y, Becker S, Lu SJ, Lanza R: Human embryonic stem cell lines derived from single blastomeres. Nature 2006;444:481-485.

46 Zhang X, Stojkovic P, Przyborsjki S, Cooke M, Armstrong L, Lako M, Stojkovic M: Derivation of human embryonic stem cells from developing and arrested embryos. Stem Cells 2006;12:2669-2676.

47 Pickering SJ, Braude PR, Patel M, Burns CJ, Trussler J, Bolton V, Minger S: Preimplantation genetic diagnosis as a novel source of embryos for stem cell research. Reprod Biomed Online 2003;7:353-364.

48 The International Stem Cell Initiative: Characterisation of human embryonic stem cell lines by the International Stem Cell Initiative. Nat Biotechnol 2007;25:803-815.

49 Baker DEC, Harrison NJ, Maltby E, Smith K, Moore HD, Shaw PJ, Heath PR, Holden H, Andrews PW: Adaptation to culture of human embryonic stem cells and oncogenesis in vivo. Nat Biotechnol 2007;25:207-215.

50 Lefort N, Perrier AL, Laabi Y, Varela C, Peschanski M: Human embryonic stem cells and genomic instability. Regen Med 2009;4:899-909.

51 Stadfeld M, Hochedlinger K: Induced pluripotency: history, mechanisms and applications. Genes Dev 2010;24:2239-2263.

52 Patel M, Yang S: Advances in reprogramming somatic cells to induced pluripotent stem cells. Stem Cell Rev 2010;6:367-380.

53 Yamanaka S, Blau HM: Nuclear reprogramming to a pluripotent state by three approaches. Nature 2010;465:704-712.

54 Takahashi K, Tanabe K, Ohnuki M, Narita M, Ichisaka T, Tomoda K, Yamanaka S: Induction of pluripotent stem cells from adult human fibroblasts by defined factors. Cell 2006;126:663-676.

55 Park IH, Zhao R, West JA, Yabuuchi A, Huo H, Ince TA, Lerou PH, Lensch MW, Daley GQ: Reprogramming of human somatic cells to pluripotency with defined factors. Nature 2008;451:141146

56 Yu J, Vodyanik MA, Smuga-Otto K, AntosiewiczBourget J, Frane JL, Tian S, Nie J, Jonsdottir GA, Ruotti V, Stewart R, Slukvin II, Thomson JA: Induced pluripotent stem cell lines derived from human somatic cells. Science 2007;318:1917-1920.
7 Kiskinis E, Eggan K: Progress toward the clinical application of patient-specific pluripotent stem cell J Clin Invest 2010;120:51-59.

58 Sun N, Longaker MT, Wu JC: Human iPS cellbased therapy considerations for clinical applications. Cell Cycle 2010;9:880-885.

59 Chin MH, Mason MJ, Xie W, Volinia S, Singer M Peterson C, Ambartsumyan G, Aimiuwu O, Richter L, Zhang J, Khvorostov I, Ott V, Grunstein M, Lavon N, Benvenisty N, Croce CM, Clark AT, Baxter T, Pyle AD, Teitell MA, Pelegrini M, Plath $\mathrm{K}$, Lowry WE: Induced pluripotent stem cells and embryonic stem cells are distinguished by gene expression signatures. Cell Stem Cell 2009;5:111-123.

60 Miura K, Okada Y, Aoi T, Okada A, Takahashi K, Okita K, Nakagawa M, Koyanagi M, Tanabe K, Ohnuki M, Ogawa D, Ikeda E, Okano H, Yamanaka S: Variation in the safety of induced pluripotent stem cell lines. Nat Biotechnol. 2009;27:743-745.

61 Lee H, Park J, Forget BG, Gaines P: Induced pluripotent stem cells in regenerative medicine: an argument for continued research on human embryonic stem cells. Regen Med 2009;4:759-769.

62 Thomson H: Bioprocessing of embryonic stem cells for drug discovery. Trends Biotechnol 2007;25:224 230.

63 Gokhale BI, Andrews PW: High-content screening of small compounds on human embryonic stem cells. Biochem Soc Trans 2010;38:1046-1050.

64 Toh WS, Lee EH, Cao T: Potential of human embryonic stem cells in cartilage tissue engineering and regenerative medicine. Stem Cell Rev 2010; doi: 10.1007/s12015-010-9222-6.

65 Seong JM, Kim BC, Park JH, Kwon IK, Mantalaris A, Hwang YS: Stem cells in bone engineering. Biomed Mater 2010;5:062001 doi: 10.1088/1748$6041 / 5 / 6 / 062001$

66 Lerou PH Lerou PH, Daley GQ: Therapeutic potential of embryonic stem cells. Blood Rev 2005; 19:321-331.

67 Strulovici Y, Leopold PL, O’Connor TP, Pergolizzi RG, Crystal RG: Human embryonic stem cells and gene therapy. Mol Ther 2007;15:850-866.

68 Arenas E: Towards stem cell replacement therapies for Parkinson's disease. Biochem Biophys Res Commun 2010;396:152-156.

69 Dantuma E, Merchant S, Sugaya K: Stem cells for the treatment of neurodegenerative diseases. Stem Cell Res Ther 2010;1:37.

70 Joyce N, Annett G, Wirthlin L, Olson S, Bauer G, Nolta JA: Mesenchymal stem cells for the treatment of neurodegenerative disease. Regen Med 2010;5:933-946.

71 Heit JJ, Kim SK: Embryonic stem cells and islet replacement in diabetes mellitus. Ped Diabetes 2004;5:5-15

72 Wagner RT, Lewis J, Cooney A, Chan L: Stem cell approaches for the treatment of type 1 diabetes mellitus. Transl Res 2010;156:169-179.

73 Caspi O, Gepstein L: Regenerating the heart using human embryonic stem cells - from cell to bedside. Isr Med Assoc J 2006;8:208-214.

74 Kusuma S, Gerecht S: Engineering blood vessels using stem cells: innovative approaches to treat vascular disorders. Expert Rev Cardiovasc Ther 2010;8:1433-1445.

75 Mason C, Manzotti M: Regen: the industry responsible for cell-based therapies. Regen Med 2009;4: 783-785.

76 Lysaght MJ, Jaklenac A, Deweerd E: Great expectations: private sector activity in tissue engineering, regenerative medicine and stem cell therapeutics. Tissue Eng Part A 2008;14:301-315. 
77 MaRS Report: Regenerative Medicine Industry Briefing. 2009. www.marsdd.com/news-insights/ mars-reports/regenerative-medicine-industry-briefing/.

78 Clinical Trials Gov Search: mesenchymal stem cel OR adult stem cell I Open Studies I stem cell transplant. Results listed at: htttp://clinicaltrials.gov/ct2/ results?term $=$ mesenchymal + stem + cell $+O R+$ adult + st em+cell and recr $=$ Open and rslt $=$ and type $=$ and cond $=$ and intr $=$ stem+cell+transplant $*$ and outc $=$ and lead $=$ and spons $=$ and id $=$ and state $1=$ and cntry $1=$ and state $2=$ and cntry $2=$ and state $3=$ and cntry3 $=$ and locn $=$ and gnd $r=$ and $r c r_{-} s=$ and $r c r_{-} e$ $=$ and lup_s $=$ and lup_e =. Accessed January 8, 2011.

79 Salem HK, Thiemerrmann T: Mesenchymal stromal cells: current understanding and clinical status. Stem Cells 2010;28:585-596

80 Bifari F, Lisi, V, Mimiola E, Pasini A,Krampera M: Immune modulation by mesenchymal stem cells. Transfus Med Hemother 2008;35:194-204.

81 Wise J: Stroke patients take part in 'milestone' UK trial of stem cell therapy. BMJ 2010;341:c6574.

82 Mayor S: First patient enters trial to test safety of stem cells in spinal injury.BMJ 2010;341:c5724.

83 EU Directive2003/94/EC: Laying down the principles of good manufacturing practice in respect of medicinal products for human use and investigational products for human use. http://eur-lex.europa. eu/LexUriServ/LexUriServ.do? uri = OJ:L:2003:262 0022:0026:EN:PDF

84 Unger C, Skottman H, Blomberg P, Diber MS, Hovatta O: Good manufacturing practice and clinical human embryonic stem cell lines. Human Mol Genet 2008;17(R1):R48-R53.

85 Sensebe L, Bourin P, Tarte K: Good manufacturing practices production of mesenchymal stem/ stromal cells. Human Gene Ther 2011;22:1-8.

86 International Conference on Harmonisation of Technical Requirements for Registration of Pharmaceuticals for Human Use: Quality Guidelines. www.ich.org/products/guidelines/quality/article/ quality-guidelines.html.

87 Ciaverrella D: Haematopoeitic stem cell processing and storage. Biotechnology 1991:19:317-349.

88 Armitage S: Collection and processing of cord blood units; in Cohen SBA, Gluckman E, Rubenstein P, Madrigal JA (eds): Cord Blood Characteristics: Role in Stem Cell Transplantation. London, Martin Dunitz, 2000, pp129-148.

89 Bosse R, Singhofer-Wowra M, Rosenthal F, Schulz $\mathrm{G}$ : Good manufacturing practice production of human stem cells for somatic cell and gene therapy. Stem Cells 1997;15(suppl 2):275-280.

90 International Standards for Cellular Therapy Product Collection, Processing and Administration, 4th ed. Joint Accreditation Committee ISCT and EBMT (JACIE). 2008

91 International Standards for Cord Blood Collection, Processing and Release for Administration. 4th edition. Joint Accreditation Committee ISCT and EBMT (JACIE). 2010.

92 Rayment EA, Williams DJ: Concise review: mind the gap: challenges in characterisation and quantifying cell and tissue-based therapies for clinical translation. Stem Cells 2010;28:996-1004.

93 Stacey G: Risk assessment of cell culture procedures; in Stacey G, Davis J (eds): Medicines from Animal Cell Culture. Chichester, Wiley and Sons, 2007, pp 569-587.

94 Stacey G: Standardisation of cell culture procedures; in Stacey G, Davis J (eds): Medicines from Animal Cell Culture. Chichester, Wiley and Sons, 2007, pp 589-601.
95 Berz D, McCormack, EM, Winer ES, Colvin GA Quesenberry PJ: Cryopreservation of hematopoietic stem cells. Am J Hematol 2007;82:463-472.

96 Choi CW, Kim BS, Seo JH, Shin SW, Kim YH, Kim JS: Long-term engraftment stability of peripheral blood stem cells cryopreserved using the dump-freezing method in a -80 degrees $\mathrm{C}$ mechanical freezer with $10 \%$ dimethyl sulphoxide. Int J Hematol 2001;73:245-250.

97 Galmes A, Gutiérrez A, Sampol A, Canaro M, Morey M, Iglesias J, Matamoros N, Duran MA, Novo A, Bea MD, Galán P, Balansat J, Martínez J, Bargay J, Besalduch J: Long-term hematological reconstitution and clinical evaluation of autologous peripheral blood stem cell transplantation after cryopreservation of cells with $5 \%$ and $10 \%$ dimethylsulfoxide at -80 degrees $\mathrm{C}$ in a mechanical freezer. Haematologica 2007;92:986-989.

98 Perez-Oteyza J, Bornstein R, Corral M, Hermosa V, Alegre A, Torrabadella M, Ramos P, Garcia J, Odriozola J, Navarro JL: Controlled-rate versus uncontrolled-rate cryopreservation of peripheral blood progenitor cells: a prospective multicenter study. Group for Cryobiology and Biology of Bone Marrow Transplantation (CBTMO), Spain. Haematologica 1998;83:1001-1005.

99 Hunt CJ, Pegg DE, Armitage SE: Optimising cryopreservation protocols for haematopoietic progenitor cells: A methodological approach for umbilical cord blood. Cryo Lett 2006;27:73-85.

100 Woods EJ, Pollok KE, Byers MA, Perry BC, Purtteman J, Heimfeld S, Gao D: Cord blood stem cell cryopreservation. Transfus Med Hemother 2007;34:276-285.

101 Hunt CJ, Armitage SE, Pegg DE: Cryopreservation of umbilical cord blood: 2. tolerance of CD34+ cells to multimolar dimethyl sulphoxide and the effect of cooling rate on the recovery after freezing and thawing. Cryobiology 2003;46: 76-87.

102 Rowley SD, Anderson GL: Effect of DMSO exposure without cryopreservation on hematopoietic progenitor cells. Bone Marrow Transplant 1993;11:389-393.

103 Rubinstein P, Dobrila L, Rosenfield RE, Adamson JW, Migliaccio G, Migliaccio AR, Taylor PE, Stevens CE: Processing and cryopreservation of placental/umbilical cord blood for unrelated bone marrow reconstitution. Proc Natl Acad Sci U S A 1995;92:10119-10122.

104 Woods EJ, Liu J, Pollok K, Hartwell J, Smith FO, Williams DA, Yoder MC, Critser JK: A theoretically-optimised method for cord blood stem cell cryopreservation. J Hematother Stem Cell Res 2003;12:341-350.

105 Hayakawa J, Joyal EG, Gildner JF, Washington KN, Phang OA, Uchida N, Hsieh MM, Tisdale JF: 5\% dimethyl sulfoxide (DMSO) and pentastarch improves cryopreservation of cord blood cells over 10\% DMSO. Transfusion. 2010;50: 2158-2166.

106 McCullough J, Haley R, Clay M, Hubel A, Lindgren B, Moroff G: Long-term storage of peripheral blood stem cells frozen and stored with a conventional liquid nitrogen technique compared with cells frozen and stored in a mechanical freezer. Transfusion 2010;50:808-819.

107 Buchanan SS, Gross SA, Acker JP, Toner M, Carpenter JF, Pyatt DW: Cryopreservation of stem cells using trehalose: evaluation of the method using a human hematopoietic cell line. Stem Cells Dev 2004;13:295-305.
108 Thirumala S, Goebel WS, Woods EJ: Clinical grade adult stem cell banking. Organogenesis 2009;5:143-154.

109 Liu G, Zhou H, Li Y, Li G, Cui L, Liu W, Cao Y: Evaluation of the viability and osteogenic differentiation of cryopreserved human adipose-derived stem cells. Cryobiology 2008;57:18-24.

110 Woods EJ, Perry BC, Hockema JJ Larson L, Zhou D, Goebel WS: Optimized cryopreservation method for human dental pulp-derived stem cells and their tissues of origin for banking and clinical use. Cryobiology 2009;59:150-157.

111 Iwatani, M, Ikegami K, Kremenska Y, Hattori N, Tanaka S, Yagi S, Shiota K: Dimethyl sulphoxide has an impact on epigenetic profile in mouse embryoid body. Stem Cells 2006;24:2549-2556.

112 Adler S, Pellizer C, Paparella M, Hartung T Bremer S: The effects of solvents on embryonic stem cell differentiation. Toxicol In Vitro 2006; 20:265-271.

113 Thirumala S, Wu X, Gimble JM, Devireddy RV: Evaluation of polyvinylpyrrolidone as a cryoprotectant for adipose tissue-derived adult stem cells. Tissue Eng Part C Methods 2010;16:783-792.

114 Thirumala S, Wu X, Gimble JM, Devireddy RV: Evaluation of methylcellulose and dimethyl sulphoxide as cryoprotectants in a serum-free freezing media for the cryopreservation of adiposederived adult stem cells. Stem Cells Dev 2010;19: 513-522.

115 Lui Y, Xu X, Ma X, Martin-Rendon E, Watt S, Cui Z: Cryopreservation of human bone marrowderived mesenchymal stem cells with reduced dimethyl sulphoxide and well-defined freezing solutions. Biotechnol Prog 2010;26:1635-1643.

116 Scheinkonig C, Kappicht S, Kolb HJ, Schleuning M: Adoption of long-term cultures to evaluate the cryoprotective potential of trehalose for freezing hematopoietic stem cells. Bone Marrow Transplant 2004;34:531-536.

117 Rodrigues JP, Paraguassu-Braga FH, Carvalho L, Abdelhay E, Bouzas LF Porto LC: Evaluation of trehalose and sucrose as cryoprotectants for hematopoietic stem cells of umbilical cord blood. Cryobiology 2008;56:144-151.

118 Reubinoff BE, Pera MF, Vajta G, Trounson AO: Effective cryopreservation of human embryonic stem cells by the open pulled straw vitrification method. Human Reprod 2001;16:2187-2194.

119 Zhou CQ, Mai QY, Li T, Zhaung GJ: Cryopreservation of human embryonic stem cells by vitrification. Chin Med J (Engl) 2004;117:1050-1055.

120 Ha YS, Jee BC, Suh CS, Kim HS, Oh SY, Kim $\mathrm{AH}$, Moon SY: Cryopreservation of human embryonic stem cells without the use of a programmable freezer. Human Reprod 2005;20:1779-1785.

121 Heng BC, Kuleshova LL, Bested SM, Liu H, Cao T: The cryopreservation of human embryonic stem cells. Biotechnol Appl Biochem 2005;41:97104.

122 Brook FA: Procedures for deriving ES cell lines from the mouse; in Notarianni E, Evans MJ (ed): Embryonic Stem Cells. A Practical Approach. Oxford, Oxford University Press, 2006, pp 7-40.

123 Suemori H, Sasai Y, Umenda K, Nakatsuji N: ES cell lines from the cynomologus monkey (Macaca fasicularis); in Notarianni E, Evans MJ (ed): Embryonic Stem Cells. A Practical Approach. Oxford, Oxford University Press, 2006, pp 294-319.

124 Amit M, Carpenter MK, Inokuma MS, Chiu CP Harris CP, Waknitz MA, Itskovitz-Eldor J, Thomon JA: Clonally derived human embryonic stem cell lines maintain pluripotancy and proliferative potential for prolonged periods of culture. Dev Biol 2000;227:271-278. 
125 Pegg DE: The role of vitrification techniques of cryopreservation in reproductive medicine. Human Fertil (Camb) 2005;8:231-239.

126 Moon, JE Lee JR, Jee BC, Suh CS, Kim SH, Lim HJ, Kim HK: Successful vitrification of human amnion-derived mesenchymal stem cells. Human Reprod 2008;23:1760-1770.

127 Vajta G, Nagy ZP: Are programmable freezers still needed in the embryo laboratory? Review on vitrification. Reprod Biomed Online 2006;12:779 796.

128 Kurata H, Takakuwa K, Tanaka K: Vitrification of hematopoietic progenitor cells obtained from human cord blood. Bone Marrow Transplant 1994;14:261-263.

129 Richards M, Fong CY, Tan S, Chan WK, Bongso A: An efficient and safe xeno-free cryopreservation method for the storage of human embryonic stem cells. Stem Cells 2004;22:779-789.

130 Vajta G, Holm P, Kuwayama M, Booth PJ, Jacobsen H, Greve T, Callensen H: Open pulled straw (OPS) vitrification: a new way to reduce cryoinjuries of bovine ova and embryos. Mol Reprod Dev 1999;51:53-58.

131 Hunt CJ, Timmons PM: Cryopreservation of human embryonic stem cell lines, in Day JG, Stacey G (ed): Cryopreservation and Freeze Drying Protocols. Methods in Molecular Biology, vol 368. Totowa, Humana Press, 2007, chapter 18.

132 Vajta G, Booth PJ, Holm P, Greve T, Callesen H: Successful vitrification of early stage bovine in vitro produced embryos with the open pulled straw (OPS) method. Cryo Letters 1997;18:191-195.

133 Heng BC, Bested SM, Chan SW, Cao T: A proposed design for the cryopreservation of intact and adherent human embryonic stem cell colonies. In Vitro Cell Biol Dev - Animal 2005;41:77-79.

134 Li T, Zhou C, Liu C, Mai Q, Zhuang G: Bulk vitrification of human embryonic stem cells. Human Reprod 2008;23:358-364.

135 Li T, Mai Q, Gao, J, Zhou C: Cryopreservation of human embryonic stem cells with a bulk vitrification method. Biol Reprod 2010;82:848-853.

136 Steyaert SR, Leroux-Rouls GG, Dhont M: Infections in IVF: review and guidelines. Human Reprod Update 2000;6:432-441.

137 Bielanski A, Vajta G: Risk of contamination of germplasm during cryopreservation and cryobanking in IVF units. Human Reprod 2009;24: 2457-2467.

138 Hawkins AE, Zuckerman MA, Briggs M, Gilson RJ, Goldstone AH, Brink NS, Tedder RS: Hepatitis B transmission neucleotide sequence analysis: linking an outbreak of acute hepatitis B to contamination of a cryopreservation tank. J Virol Methods 1996;60:81-88.

139 Mazzilli F, Delfino M, Imbrogno N, Elia J, Dondero F: Survival of micro-organisms in cryostorage of human sperm. Cell Tissue Banking 2006;7: 75-79.

140 McBurnie LD, Bardo B: Validation of sterile filtration of liquid nitrogen. Pharm Technol North America 2002;26:74-82.

141 Kuleshova LL, Shaw JM: A strategy for rapid cooling of mouse embryos within a double straw to eliminate the risk of contamination during storage in liquid nitrogen. Human Reprod 2000; 15:2604-2609.

142 Kuleshova LL, Tan FCK, Magalhaes R, Gouk SS, Lee KH, Dawe GS: Effective cryopreservation of neural stem and progenitor cells without serum or proteins by vitrification. Cell Transplant 2009; 18:135-144.
143 Nishigaki T, Teruma Y, Suemori H, Iwata H: Cryopreservation of primate embryonic stem cells with chemically-defined solutions without DMSO. Cryobiology 2010;60:159-164.

144 Dinnyés A, Dai Y, Jiang S, Yang X: High developmental rates of vitrified bovine oocytes following parthenogenetic activation, in vitro fertilization, and somatic cell nuclear transfer. Biol Reprod. 2000;63:513-518.

145 Aerts JM, De Clercq JB, Andries S, Leroy JL, Van Aelst S, Bols PE: Follicle survival and growth to antral stages in short-term murine ovarian cortical transplants after cryologic solid surface vitrification or slow-rate freezing. Cryobiology 2008;57:163-169.

146 Beebe LF, Bouwman EG, Mcllfatrick SM, Nottle MB: Piglets produced from in vivo blastocysts vitrified using the cryologic vitrification method (solid surface vitrification) and a sealed storage container. Theriogenology 2011; doi:10.1016/j. theriogenology.2010.11.043

147 Udy GB, Evans MJ: Microplate DNA preparation, PCR screening and cell freezing for gene targeting in embryonic stem cells. Biotechniques 1994;17:887-894.

148 Hunt CJ: The banking and cryopreservation of human embryonic stem cells. Transfus Med Hemother 2007;34:293-304.

149 Katkov II, Kim MS, Bajpai R, Altman YS, Mercola M, Loring JF, Terskikh AV, Snyder EY, Levine F: Cryopreservation by slow cooling with DMSO diminished production of Oct-4 pluripotency marker in human embryonic stem cells. Cryobiology 2006;53:194-205.

150 Kashuba Benson CM, Benson JD, Critser JK: An improved cryopreservation method for a mouse embryonic stem cell line. Cryobiology 2008;56: 120-130.

151 Ware CB, Nelson AM, Blau CA: Controlled-rate freezing of human ES cells. Biotechniques 2005; 38:879-883.

152 Yang PF, Hua TC, Wu J, Chang ZH, Tsung HC, Cao YL: Cryopreservation of human embryonic stem cells: a protocol by programmed cooling. Cryo Letters 2006;27:361-368.

153 Valbuena D, Sanchez-Luengo S, Galan A, Sanchez E, Gomez E, Poo ME, Ruiz V, Genbacev O, Krtolica A, Pellicer A, Moreno R, Simon C: Efficinet method for slow cryopreservation of human embryonic stem cells in xeno-free conditions. RBM Online 2008;17:127-135.

154 Li Y, Tan J, Li L: Comparison of three methods for cryopreservation of human embryonic stem cells. Fertil Steril 2010;93:999-1005.

155 Lee JY, Lee JE, Kim DK, Yoon TK, Chung HM, Lee DR: High concentration of synthetic serum, stepwise equilibration and slow cooling as an efficient technique for large-scale cryopreservation of human embryonic stem cells. Fertil Steril 2010; 93:976-985.

156 Baran SW, Ware CB: Cryopreservation of rhesus macaque embryonic stem cells. Stem Cell Dev 2007;16:339-344.

157 Meryman HT: Cryopreservation of living cells: principles and practice. Transfusion 2007;476:935945.

158 Acker JP, Larese A, Yang H, Petrenko A, McGann LE: Intracellular ice formation is affected by cell interactions. Cryobiology 1999;38:363-371.

159 Berger WK, Uhrik B: Freeze-induced shrinkage of individual cells and cell-to-cell propagation of intracellular ice in chains from salivary glands. Experientia 1996;15:843-850.
160 Acker JP, Elliot JAW, McGann LE: Intracellular ice propagation: Experimental evidence for ice growth through membrane pores. Biophys J 2001; 81:1389-1397.

161 Armitage WJ, Juss BK: The influence of cooling rate on survival of frozen cells differs in monolayers and in suspensions. Cryo Letters 1996;17: 213-218.

162 Sathananthan H, Pera M, Trounson A: The fine structure of human embryonic stem cells. Reprod Biomed Online 2002;4:56-61.

163 Wong, RCB, Pebay A, Nguyen LTV, Koh KLL, Pera MF: Presence of functional gap junctions in human embryonic stem cells. Stem Cells 2004;22: 883-889.

164 De Maio A, Vega VL, Contreras JE: Gap junctions, homeostasis and injury. J Cell Physiol 2002;191:269-282.

165 Wong RCB, Pera MF, Pebay A: Role of gap junctions in embryonic and somatic stem cells. Strem Cell Rev 2008;4:283-292.

166 Irimia D, Karlsson JO: Kinetics and mechanisms of intracellular ice propagation in a micropatterned tissue construct. Biophysics J 2002;82: 1858-1868.

167 Toner M, Cravalho EG, Karel M: Thermodynamics and kinetics of intracellular ice formation during freezing of biological cells. J Appl Phys 1990;67:1582-1593.

168 Ji L, de Pablo J, Palacek SP: Cryopreservation of adherent human embryonic stem cells. Biotechnol Bioeng 2004;88:299-312.

169 Baust JG, Gao D, Baust JM: Cryopreservation an emerging paradigm change. Organogenesis 2009; 5:90-96.

170 de Boer F, Dräger AM, Pinedo HM, Kessler FL, Monnee-van Muijen M, Weijers G, Westra G, van der Wall E, Netelenbos T, Oberink JW, Huijgens PC, Schuurhuis GJ: Early apoptosis largely accounts for functional impairment of CD34+ cells in frozen-thawed stem cell grafts. J Hematother Stem Cell Res 2002;11:951-963.

171 Heng BC, Ye CP, Lui H, Toh WS, Rufaihah AJ, Bay BH, Ge Z, Ouyang HW, Lee EH, Cao T: Loss of viability during freeze-thaw of intact and adherent human embryonic stem cells with conventional slow-cooling protocols is predominantly due to apoptosis rather than cellular necrosis. $\mathrm{J}$ Biomed Sci 2006;13:433-435.

172 Heng BC, Ye CP, Lui H, Toh WS, Rufaihah AJ, Cao T: Kinetics of cell death of frozen-thawed human embryonic stem cell colonies is reversibly slowed down by exposure to low temperatures. Zygote 2006;14:341-348.

173 Xu X, Cowley S, Flaim CJ, James W, Seymour L, Cui Z: The roles of apoptotic pathways in the low recovery rate after cryopreservation of dissociated human embryonic stem cells. Biotechnol Prog 2009;26:827-837.

174 Heng BC, Clement MV, Cao T: Caspase inhibitor Z-VAD-FMK enhances the freeze-thaw survival rate of human embryonic stem cells: Biosci Rep 2007;27:257-264.

175 Olson MF: Applications for ROCK kinase inhibition. Curr Opin Cell Biol 2008;20:242-248.

176 Watanabe K, Ueno M, Kamiya D, Nishiyama A, Matsumura M, Wataya T, Takahashi JB, Nishikawa S, Nishikawa S, Muguruma K, Sasai Y: A ROCK inhibitor permits survival of dissociated human embryonic stem cells. Nat Biotechnol 2007;25:681-686.

177 Krawetz RJ, Li X, Rancourt DE: Human embryonic stem cells: caught between a ROCK inhibitor and a hard place. Bioessays 2009;31:336-343. 
178 Li X, Krawetz R, Liu S, Meng G, Rancourt DE: ROCK inhibitor improves survival of cryopreserved serum/feeder-free single human embryonic stem cells. Hum Reprod 2009;24:580-589.

179 Li X, Meng G, Krawetz R, Liu S, Rancourt DE: The ROCK inhibitor Y-27632 enhances the survival rate of human embryonic stem cells following cryopreservation. Stem Cells Dev 2008;17: 1079-1086.

180 Martin-Ibañez R, Unger C, Strömberg A, Baker D, Canals JM, Hovatta O: Novel cryopreservation method for dissociated human embryonic stem cells in the presence of a ROCK inhibitor. Hum Reprod 2008;23:2744-2754.

-181 Gauthaman K, Fong CY, Subramanian A, Biswas A, Bongso A: ROCK inhibitor Y-27632 increases thaw-survival rates and preserves stemness and differentiation potential of human Wharton's jelly stem cells after cryopreservation. Stem Cell Rev 2010;6:665-676.

182 Heng BC: Effect of Rho-associated kinase (ROCK) inhibitor Y-27632 on the post-thaw viability of cryopreserved human bone marrowderived mesenchymal stem cells. Tissue Cell 2009; 41:376-380.

183 Claassen DA, Desler MM, Rizzino A: ROCK inhibition enhances the recovery and growth of cryopreserved human stem cells and human induced pluripotent stem cells. Mol Reprod Dev 2009;76:722-732.

184 Mollamohammadi S, Taei A, Pakzad M, Totonchi M, Seifinejad A, Masoudi N, Baharvand H: A simple and efficient cryopreservation method for feeder-free dissociated human induced pluripotent stem cells and human embryonic stem cells Hum Reprod 2009;24:2468-2476.

185 Baharvand H, Salekdeh GH, Taei A, Mollamohammadi S: An efficient and easy-to-use cryopreservation protocol for human ES and iPS cells. Nat Protoc 2010;5:588-594.

186 Martín-Ibáñez R, Strömberg AM, Hovatta O, Canals JM: Cryopreservation of dissociated human embryonic stem cells in the presence of ROCK inhibitor. Curr Protoc Stem Cell Biol 2009;10: 1C.8.1-1C.8.15.

-187 Adler S, Pellizzer C, Paparella M, Hartung T, Bremer S: The effects of solvents on embryonic stem cell differentiation. Toxicol In Vitro 2006; 20:265-271.

188 Wu CF, Tsung HC, Zhang WJ, Wang Y, Lu JH, Tang ZY, Kuang YP, Jin W, Cui L, Liu W, Cao YL: Improved cryopreservation of human embryonic stem cells with trehalose. Reprod Biomed Online 2005;11:733-739.

189 Matsumura K, Hyon S: Polyampholytes as low toxic efficient cryoprotective agents with antifreeze protein properties. Biomaterials 2009;30: 4842-4849.
190 Tereda S, Nishimura T, Sasaki M, Yamada H, Miki M: Sericin, a protein derived from silkworms, accelerates the proliferation of several mammalian cell lines including a hybridoma. $\mathrm{Cy}$ totechnology 2002;40:3-12.

191 Miyamoto Y, Teramoto N, Hayashi S, Enosawa $\mathrm{S}$ : An improvement in the attaching capability of cryopreserved human hepatocytes by a proteinaceous high molecula, sericin in the serum-free solution. Cell Transplant 2010;19:701-706.

192 Kim GA, Lee ST, Ahn JY, Park JH, Lim JM: Improved viability of freeze-thawed embryonic stem cells after exposure to glutathione. Fertil Steril 2010;94:2409-2412.

193 Skottman H, Dilber MS, Hovatta O: The derivation of clinical grade human embryonic stem cell lines. FEBS Lett 2006;580:2875-2878.

194 Unger C, Skottman H, Blomberg P, Dilber MS, Hovatta O: Good manufacturing practice and clinical-grade human embryonic stem cell lines. Hum Mol Genet 2008;17(R1):R48-53.

195 Rajala K, Lindroos B, Hussein SM, Lappalainen RS, Pekkanen-Mattila M, Inzunza J, Rozell B, Miettinen S, Narkilahti S, Kerkelä E, AaltoSetälä K, Otonkoski T, Suuronen R, Hovatta O, Skottman H: A defined and xeno-free culture method enabling the establishment of clinicalgrade human embryonic, induced pluripotent and adipose stem cells. PLoS One 2010;5:e10246.

196 Cryopreservation Solutions / Cell Freezing Media / Tissue Freezing Media. www.biocompare.com/ ProductListings/6470/Cryopreservation-SolutionsCell-Freezing-Media-Tissue-Freezing-Media.html.

197 Holm F, Ström S, Inzunza J, Baker D, Strömberg AM, Rozell B, Feki A, Bergström R, Hovatta O: An effective serum- and xeno-free chemically defined freezing procedure for human embryonic and induced pluripotent stem cells. Hum Reprod 2010;25:1271-1279.

198 Thomas RJ, Anderson D, Chandra A, Smith NM, Young LE, Williams D, Denning C: Automated, scalable culture of human embryonic stem cells in feeder-free conditions Biotechnol Bioeng. 2009; 102:1636-4164.

199 Thomas RJ, Hope AD, Hourd P, Baradez M, Miljan EA, Sinden JD, Williams DJ: Automated, serum-free production of CTX0E03: a therapeutic clinical grade human neural stem cell line. Biotechnol Lett 2009;31:1167-1172.

200 Nie Y, Bergendahl V, Hei DJ, Jones JM, Palecek SP: Scalable culture and cryopreservation of human embryonic stem cells on microcarriers. Biotechnol Prog 2009;25:20-31.

201 Amps KJ, Jones M, Baker D, Moore HD: In situ cryopreservation of human embryonic stem cells in gas-permeable membrane culture cassettes for high post-thaw yield and good manufacturing practice. Cryobiology 2010;60:344-350.
202 Heidemann HR, Lunse S, Tran D, Zhang C: Characterisation of cell-banking parameters for the cryopreservation of mammalian cell lines in 100-ml cryobags. Biotechnol Prog 2010;26:1154 1163.

203 Morris GJ, Acton E, Faszer K, Franklin A, Yin H, Bodine R, Pareja J, Zaninovic N, Gosden R: Cryopreservation of murine embryos, human spermatozoa and embryonic stem cells using a liquid nitrogen-free, controlled rate freezer. Reprod Biomed Online 2006;13:421-426.

204 McCullough J, Haley R, Clay M, Hubel A, Lindgren B, Moroff G: Long-term storage of peripheral blood stem cells frozen and stored with a conventional liquid nitrogen technique compared with cells frozen and stored in a mechanical freezer. Transfusion 2010;50:808-829.

205 Hunt CJ, Song YC, Bateson EA, Pegg DE: Fractures in cryopreserved arteries. Cryobiology 1994; 31:506-515.

206 Tomlinson M, Sakkas D: Is a review of standard procedures for cryopreservation needed? Safe and effective cryopreservation - should sperm banks and fertility centres move toward storage in nitrogen vapour? Hum Reprod 2000;15:24602463.

207 Rowley SD, Byrne DV: Low-temperature storage of bone marrow in nitrogen vapour-phase refrigerators: decreased temperature gradients with an aluminium racking system. Transfusion 1992;32: 750-754.

208 Hunt CJ, Pegg DE: Improved temperature stability in gas phase nitrogen refrigerators: the use of a copper heat shunt. Cryobiology 1996;33:544-551.

209 Kyuwa S, Nishikawa T, Kaneko T, Nakashima T, Kawano K, Nakamura N, Noguchi K, Urano T, Itoh T, Nakagata N: Experimental evaluation of cross-contamination between cryotubes containing mouse 2-cell embryos and murine pathogens in liquid nitrogen tanks. Exp Anim 2003;52:67-70.

210 Chen HI, Tsai CD, Wang HT, Hwang SM: Cryovial with partial membrane sealing can prevent liquid nitrogen penetration in submerged storage. Cryobiology 2006;53:283-287.

211 Woods EJ, Bagchi A, Goebel WS, Nase R, Vilivalam VD: Container systems for enabling commercial production of cryopreserved cell therapy products. Regen Med 2010;5:659-667.

212 Bielanski A: Non-transmission of bacterial and viral microbes to embryos and semen stored in the vapour phase of liquid nitrogen in dry shippers. Cryobiology 2005;50:206-210.

213 Bielanski A: Experimental microbial contamination and disinfection of dry (vapour) shipper dewars designed for short-term storage and transportation of cryopreserved germplasm and other biological specimens. Theriogenology 2005;63: 1964-1957. 